\title{
Kalendarium życia kulturalnego Łodzi luty-marzec 1945
}

Prezentowany fragment Kalendarium życia kulturalnego Łodzi 1945 roku to element szerzej zakrojonego projektu badawczego, mającego na celu opis kulturowo-ideologicznej rewolucji, przeprowadzonej w latach 1945-1948 przez narzuconą Polsce władzę komunistyczną oraz przez wspierających ją (lub: niesprzeciwiających się jej) pisarzy, ludzi teatru i filmu, dziennikarzy i satyryków, a także przez członków najbardziej aktywnych stowarzyszeń i organizacji młodzieżowych o profilu otwarcie komunistycznym lub kryptokomunistycznym (na czele z Akademickim Związkiem Walki Młodych „Życie”).

Polityczna ofensywa komunistów miała, jak wiadomo, zmienną dynamikę. Lata 1944-1948 - od momentu instalacji nowych władz w oswobodzonym od Niemców Lublinie aż po sfałszowane wybory i „zneutralizowanie" jedynej realnie opozycyjnej partii, czyli Polskiego Stronnictwa Ludowego Stanisława Mikołajczyka - były okresem stopniowego przejmowania kontroli nad instytucjami kultury, środkami przekazu, wydawnictwami i wszelkimi strukturami życia publicznego. Operacja ta, zaplanowana i zrealizowana z żelazną konsekwencją, prowadzona była na wielu frontach, a jej areną stały się największe i stosunkowo najmniej zniszczone podczas wojny miasta nowej Rzeczypospolitej Polskiej - Łódź i Kraków.

W związku z tym, że Warszawa niemal całkowicie została zrównana z ziemią, władze Polskiej Partii Robotniczej rozważały koncepcję przeniesienia stolicy do Łodzi. Istotnym argumentem było tu centralne usytuowanie miasta $\mathrm{w}$ strukturze przesuniętego na zachód państwa polskiego. $\mathrm{Z}$ upodobaniem akcentowano proletariacką specyfikę Łodzi, udział ludności miasta $\mathrm{w}$ - traktowanych jako prefiguracja dokonującej się właśnie

* Uniwersytet Łódzki, Wydział Filologiczny, Instytut Filologii Polskiej, Katedra Literatury i Tradycji Romantyzmu, e-mail: pdakowicz@poczta.onet.pl. 
rewolucji - wydarzeniach roku 1905. Koncepcja stołeczności Łodzi prędko upadła - negatywnie wypowiedział się na ten temat sam Józef Stalin.

Paradoksalnie, decyzja o natychmiastowym rozpoczęciu odbudowy Warszawy przyczyniła się do czasowego wzmocnienia roli największego ośrodka miejskiego leżącego w pobliżu stolicy. W Łodzi ulokowały się niektóre spośród urzędów centralnych, zaczęli tu także zjeżdżać ważni przedstawiciele życia umysłowego i kulturalnego. Władze oferowały im mieszkania (przeznaczono na ten cel dwie nowoczesne kamienice - jedną u zbiegu ul. Bandurskiego (dzisiaj al. Mickiewicza) i al. Kościuszki, drugą przy ul. Żeromskiego) oraz pracę w dynamicznie rozwijającej się, kontrolowanej przez komunistów prasie. Na pewien czas swoją centralę przeniosła do Łodzi kierowana przez Jerzego Borejszę Spółdzielnia Wydawnicza "Czytelnik".

W pierwszych miesiącach po uwolnieniu miasta spod niemieckiej okupacji osiedlili się tu między innymi Zofia Nałkowska, Pola Gojawiczyńska, Paweł Hertz, Jan Kott, Stefan Żółkiewski, Mieczysław Jastrun, Stanisław Dygat, Adolf Rudnicki, Adam Ważyk, Kazimierz Brandys, Jan Brzechwa, Zygmunt Kałużyński, Julia Hartwig, Stanisław Piętak, Erwin Axer, Stefania Grodzieńska, Jan Huszcza, Eryk Lipiński, Leon Pasternak, Stanisław Jerzy Lec.

Jednym z „magnesów” przyciągających przedstawicieli młodszego pokolenia okazały się utworzone naprędce nowe uczelnie, na czele ze zorganizowanym na bazie przedwojennej Wolnej Wszechnicy Polskiej - Uniwersytetem Łódzkim. W tej państwowej szkole wyższej studia rozpoczęły osoby, które w przyszłości miały się stać luminarzami nowej, ufundowanej na metodologii marksistowej, humanistyki lub aktywnymi uczestnikami powojennego życia literackiego i intelektualnego: Maria Janion, Maria Żmigrodzka, Tadeusz Drewnowski, Andrzej Braun, Anna Kamieńska, Waldemar Kiwilszo, Wiktor Woroszylski, Leszek Kołakowski, Mieczysława Buczkówna, Jerzy Miller i inni. Większość z nich rychło dostała się także w przestrzeń oddziaływania „Kuźnicy”, redagowanego przez Stefana Żółkiewskiego pisma kulturalno-literackiego o profilu marksistowsko-rewolucyjnym.

Opis zmian w polskiej kulturze, jakie dokonały się w latach 1945-1948, nie może być kompletny, jeśli nie uwzględni się w nim niezwykle istotnego „etapu” łódzkiego. Zapełnieniu owej dotkliwej luki w rodzimej historii literatury służyć ma przedsięwzięta przeze mnie praca. Jednym z jej ważniejszych składników będzie szczegółowe kalendarium.

Zadanie opisania i scharakteryzowania łódzkiej kultury w pierwszych miesiącach i latach powojennych sytuuje się na przecięciu kilku specjalności humanistycznych: (1) stricte filologicznej, (2) kulturoznawczej, (3) socjologicznej i (4) historyczno-politologicznej. Osoba zamierzająca przedstawić możliwie kompletny obraz tamtej epoki wykroczyć musi poza granice wąsko pojętej analizy i syntezy polonistycznej. Właśnie dlatego prezentowany fragment Kalendarium życia kulturalnego Łodzi 1945 r., składający się z szeregu zapisów ułożonych wedle porządku chronologicznego, obejmuje również najistotniejsze epizody życia politycznego i społecznego. 
W tekście posługuję się skrótami tytułów prasowych:

DE - „Dziennik Łódzki”

GL - "Głos Ludu”

PZ - „Polska Zbrojna”

$\mathrm{R}-$ - „Robotnik”

RZ - „Rzeczpospolita”

$\mathrm{W}-{ }_{\text {,Wieś }}$

Wszystkie podkreślenia $\mathrm{w}$ cytowanych fragmentach są zgodne $\mathrm{z}$ oryginalnym zapisem. Kolejne części Kalendarium będą sukcesywnie publikowane na łamach „Czytania Literatury. Łódzkich Studiów Literaturoznawczych".

\section{Przełom stycznia/lutego 1945}

1. Wizyty gości u Zofii Nałkowskiej, przebywającej we wsi Adamowizna k. Grodziska Maz. - najpierw Jarosława Iwaszkiewicza, Aleksandra Rafałowskiego i Edwarda Kozikowskiego, potem przedstawicieli władzy komunistycznej, Jerzego Putramenta i Jerzego Borejszy. Pisarka otrzymuje propozycję przeniesienia się do Łodzi.

Ta nowa rzeczywistość podpływa ku mnie i z wolna mię zagarnia. Naprzód pojawienie się z Iwaszkiewiczem - Rafałowskiego i Kozikowskiego, ostatnio redaktor Putrament i znany przed wojną Borejsza - obaj w polskich mundurach. Egzotyzm, poplątanie elementów ideologicznych i narodowych, stąpa się po terenie pełnym najdziwniejszych niespodzianek. Prasa tu nie dochodzi, ale dostałam parę numerów tych pism. Ta łagodna metoda jednak się utrzymuje z wyraźną konsekwencją. Te początki przypominają tamte z roku osiemnastego - budzą tyleż zdziwień, zastrzeżeń, niepokojów. Pewno, że i to ulegnie zmianie - ale gdy wówczas było to stopniowe zwijanie chorągiewek, tu rozwój idzie po linii ich rozwijania. Uczucie ulgi niezmiernej trwa, radość, że coś się robi, że ludzie są potrzebni. Te najwięcej budzące złych uczuć sprawy zmienianych pięćsetek są, jak się zdaje, po to, by ludzi zmusić do udziału w pracy. Wezwanie do architektów, by odbudowywali Warszawę, obiecana w tym pomoc Sowietów. Szkoły już otwierają, organizują wydawnictwa. To, co nadciąga, będzie naturalnie bardzo burzliwe, bardzo w tutejszych warunkach oporne i trudne. Ale to, co było, minęło naprawdę, ten koszmar jednak się skończył. - Borejsza proponuje, bym była prezesem Komisji do badania zbrodni w Oświęcimiu. W Łodzi powstają pisma, jest dom z mieszkaniami poniemieckimi dla pisarzy. Chcą mię tam zabrać samochodem, ale jestem jeszcze chora. Wzięli Węzty życia do „Odrodzenia”. Chcą drukować nowe, piąte wydanie Granicy. (Z. Nałkowska, Dzienniki, t. 6: 1945-1954. Część 1 [1945-1948], opracowanie, wstęp i komentarz H. Kirchner, Warszawa 2000, s. 40; zapisek z 10 lutego 1945) 


\title{
1 lutego 1945, czwartek
}

1. „Do Warszawy przybywają „prezydent KRN” Bolesław Bierut, „premier” Edward Osóbka-Morawski, „wicepremierzy” Władysław Gomułka i Stanisław Janusz oraz inni przedstawiciele samozwańczych władz komunistycznych; podczas pierwszego posiedzenia "rządu” postanowiono „rozmieścić czasowo część urzędów państwowych [...] w okolicach Warszawy i Łodzi". (Przeniesienie siedziby Rządu Tymczasowego do Warszawy, DŁ 1945, nr 4, s. 1)

2. Ukazuje się pierwszy numer „Dziennika Łódzkiego” (red. nacz. Anatol Mikułko). Na pierwszej stronie, oprócz doniesień z frontu i informacji o deklarowanej przez ZSRS pomocy w odbudowie Warszawy, syntetyczny program dla Łodzi powojennej (Łódź) oraz fragment Kwiatów polskich Juliana Tuwima (Modlitwa); na dalszych stronach między innymi informacja o ponownym uruchomieniu łódzkiego oddziału Polskiej Akcyjnej Spółki Telefoniczne (PAST) i otwarciu Domu Kultury Robotniczej (,w dawnym pałacu zimowym Poznańskiego przy ul. Gdańskiej Nr 32")

\begin{abstract}
Łódź ma przed sobą wielką przyszłość i perspektywy. Warszawa została zburzona przez zaborcę. Oczywiście dźwignie się z gruzów - to ambicja każdego Polaka, całego narodu. Ale w tej chwili Łódź jest największym ocalałym miastem polskim. Siłą faktu zogniskuje się tu nie tylko życie przemysłowe, lecz i w znacznej mierze - życie kulturalne. (Łódź, DŁ 1945, nr 1, s. 1)
\end{abstract}

\section{nie wcześniej niż 1 lutego 1945, czwartek}

1. „W pierwszych dniach lutego" do Łodzi przenoszą się Zarząd Główny Spółdzielni Wydawniczej "Czytelnik” oraz redakcja dziennika „Rzeczpospolita". Spółdzielnia przejmuje drukarnię przy ul. Żwirki 2. (J. R., Dotychczasowy dorobek „Czytelnika”, „Książka i Kultura” 1945, nr 1, s. 8)

\section{2 lutego 1945, piątek}

1. Walne zebranie informacyjne łódzkiego oddziału Związku Nauczycielstwa Polskiego w siedzibie Związku, ul. Zachodnia 72. (Komunikaty, DE 1945 , nr 2, s. 4)

2. W prasie:

2.1. recenzja sowieckiego filmu Tęcza, nakręconego na podstawie powieści Wandy Wasilewskiej, anonsowanego jako „ewenement dnia”.

Aktorzy nieznani. Gra ich jest niezrównana. Właściwie to nie jest gra - to jest ŻYCIE nagłe, twarde, przesiąkłe łzami i krzykiem rozpaczy, życie ludzi, których nie łamie wraża pięść niemieckiego oprawcy, życie ludzi, którzy bez cienia strachu patrzą w wyciągnięte ku nim lufy rewolwerów, 
życie miliona matek, milionów dzieci, które z karabinem w ręku bronią jednej wspólnej MATKI - Związku Radzieckiego. („Tęcza” [recenzja z filmu], DŁ 1945, nr 2, s. 4)

\section{nie wcześniej niż 2 lutego 1945, piątek}

1. Po zainstalowaniu się w Łodzi, gdzie ma niebawem współredagować „Kuźnicę”, Jan Kott wraca na jakiś czas do Krakowa.

Wróciłem do Krakowa autem z obstawą chyba już po tygodniu. Droga była jeszcze niezupełnie przetarta, ale dojechaliśmy bez przeszkód. (J. Kott, Przyczynek do biografii. Zawat serca, Kraków 1994, s. 187)

\section{3 lutego 1945, sobota}

1. Zebranie organizacyjne pracowników księgarskich w lokalu księgarni S. Sepelt, ul. Piotrkowska 47. (Komunikaty, DŁ 1945, nr 2, s. 4)

2. Zebranie organizacyjne dyrektorów i organizatorów szkół średnich ogólnokształcących w siedzibie Kuratorium Okręgu Szkolnego Łódzkiego, ul. Cegielniana 157. (Zebranie dyrektorów szkót, DŁ 1945, nr 3, s. 4)

3. Zebranie członków PPR i ZWM w Domu Kultury Robotniczej; organizacja sekcji: 1) muzycznej, orkiestry symfonicznej, dętej, chóru mieszanego; 2) dramatycznej; 3) literackiej. (Dom Kultury Robotniczej, DŁ 1945, nr 4, s. 4)

4. W prasie:

4.1. informacja o reakcji łódzkich kolejarzy na oswobodzenie miasta.

Zebranie zwołane przez okręgową komisję Z. Z., przez pracowników Kolei Łódź Fabryczna, wysłuchało referat [sic!] tow. Przybyła. Na zebraniu tym uchwalono jednogłośnie następujące rezolucje: Kolejarze Łódź Fabryczna przesyłają pozdrowienia bohaterskiej Czerwonej Armii i jej wodzowi Marszałkowi Stalinowi i podziękowanie za oswobodzenie naszych ziem Naczelnemu Wodzowi Roli-Żymirskiemu [sic!] i Armii Polskiej za jej bohaterską walkę, Tymczasowemu Rządowi w Warszawie jako jedynemu przedstawicielowi Narodu Polskiego. Robotnicy ZZ potępiają politykę rządu londyńskiego, zmierzającą po linii polskiej reakcji. (Kolejarze Łodzi witaja Rząd Tymczasowy Polski i Marszatka Stalina, DŁ 1945, nr 3, s. 2)

\section{3-5 lutego 1945, sobota-poniedziałek}

1. Przebywający w Łodzi zagraniczni korespondenci prasowi oglądają getto, cmentarz żydowski, miejsce masakry więźniów na Radogoszczu, zwiedzają Zakłady Przemysłowe Scheiblera i Grohmana, spotykają 
się m.in. z I. Logą-Sowińskim i H. Mincem. (Zagraniczni dziennikarze w Łodzi, DŁ 1945, nr 5; Dziennikarze zagraniczni zwiedzili Łódź, GL 1945, nr 30 [69], s. 4)

\section{4 lutego 1945, niedziela}

1. Na pierwszej stronie „Dziennika Łódzkiego” udostępniona zostaje treść depeszy nadesłanej z Nowego Jorku przez Juliana Tuwima:

Pełen tęsknoty do mojego umiłowanego miasta rodzinnego, wyzwolonego przez bohaterskich żołnierzy radzieckich, ślę łodzianom najserdeczniejsze pozdrowienia. Składam hołd męczennikom, zamordowanym przez niemieckich zbrodniarzy faszystowskich. Uczynię wszystko, by możliwie jak najszybciej znaleźć się wśród was i razem z wami pracować dla Łodzi i dla nowej, wolnej Polski. Łodzianie przebywający obecnie w Ameryce organizują pomoc dla was. (Depesza Juliana Tuwima do mieszkańców Łodzi, DŁ 1945, nr 4, s. 1)

2. Ukazuje się pierwszy łódzki numer „Głosu Ludu” (1945, nr 29 [68]), organu KC PPR; adres redakcji: ul. Piotrkowska 86, red. nacz. Roman Werfel. Wcześniej gazeta była wydawana w Lublinie; od teraz - jedno wydanie w Łodzi, drugie - w Lublinie. Na 1. stronie programowo-propagandowy artykuł wstępny Łódź - miasto pracy $i$ walki.

Od dnia 4 lutego 1945 roku główne wydanie "Głosu Ludu" wychodzi w Łodzi - dla Łodzi i Warszawy. Pismo nasze, stworzone przez Polską Partię Robotniczą na terytorium wyzwolonym w lecie ub. roku, staje mocną stopą W STOLICY POLSKI ROBOTNICZEJ. Łódź była od dziesięcioleci twierdzą naszego ruchu - antyfaszystowskiego ruchu robotniczego. Jesteśmy tu USWOICH TOWARZYSZY, W DOMU. Przenosząc się do Łodzi, "Głos Ludu” powtórzyć może tylko słowa, zawarte w pierwszym numerze: będziemy wierni Polsce i wierni ludowi polskiemu, BĘDZIEMY SŁUŻYLI NARODOWI POLSKIEMU i SPRAWIE ROBOTNICZEJ”. (,Głos Ludu” w Łodzi, GL 1945, nr 29 [68], s. 1)

Sanacja, która rozpanoszyła się w Polsce po odbudowie niepodległego państwa, nie lubiła Łodzi. Zaciętym reakcjonistom nienawistny był głęboki demokratyzm łódzkiego proletariatu. Łódź przeżywała stały kryzys; bezrobocie nie przestawało gnębić robotnika łódzkiego. [...] Serdeczne stosunki, jakie po tej wojnie istnieć będą między Polską a Związkiem Radzieckim otwierają nowe perspektywy i przed przemysłem łódzkim. Nie będzie w Łodzi bezrobocia po tej wojnie i każdy, kto zechce pracować, znajdzie w niej pracę i chleb. [...] Idzie pomoc zza Wisły, [...] znad Dniepru, znad Oki, znad Wołgi - pomoc z sojuszniczego Związku Radzieckiego.

Łódź polska, Łódź patriotyczna, Łódź - miasto świadomego, walczącego proletariatu wchodzi w nową erę - erę wspaniałego rozkwitu! (Łódź - miasto pracy i walki, GL 1945, nr 29 [68], s. 1) 


\section{5 lutego, poniedziałek}

1. Odbywa się zebranie pracowników kinowych.

Łódź posiada ogółem 13 zupełnie niezniszczonych kin i 25 aparatów kinowych. Części maszyn będące w prywatnym posiadaniu są rekwirowane i kompletowane przez należących do Związku Zawodowego monterów specjalistów. Należy zaznaczyć, że pięć kin już od dwóch tygodni zaspokaja głód kina. (Kina łódzkie, DŁ 1945, nr 6, s. 3)

2. Zgodnie z rozporządzeniem Kuratorium Okręgu Szkolnego Łódzkiego w Łodzi rozpoczynają się zapisy do szkół średnich; wstępna lista placówek wznawiających swoją działalność zostaje opublikowana w gazetach z 6 lutego 1945 (Zapisy do szkót średnich, GL 1945, nr 30 [69], s. 3): (1) Państwowe Gimnazjum im. M. Kopernika, ul. Żeromskiego 10; (2) Państwowe Liceum im. G. Narutowicza, ul. Targowa 63; (3) Państwowe Gimnazjum im. S. Żeromskiego, ul. Pierackiego 11/13 (ul. Roosevelta); (4) Państwowe Gimnazjum im. E. Szczanieckiej, ul. Pomorska 16; (5) Gimnazjum żeńskie, ul. Wólczańska 121/123; (6) Gimnazjum żeńskie, ul. Piotrkowska 187; (7) Gimnazjum miejskie, ul. Sienkiewicza 46; (8) Gimnazjum męskie A. Zimowskiego, ul. Boczna 5; (9) Gimnazjum żeńskie Z. Pętkowskiej, ul. Wólczańska 55; (10) Gimnazjum męskie im. W. Reymonta, ul. Piotrkowska 114; (11) Gimnazjum męskie, ul. Żeromskiego 10; (12) Gimnazjum żeńskie H. Miklaszewskiej, ul. Narutowicza 59a; (13) Gimnazjum żeńskie J. Czapczyńskiej, ul. Narutowicza 56.

3. O. Tomasz Rostworowski TJ przyjeżdża do Łodzi i - wbrew planom - zostaje na miejscu. Obejmuje stanowisko prefekta w trzech szkołach średnich: w Państwowym Liceum Pedagogicznym przy ul. Lipowej 49, w Państwowym Gimnazjum i Liceum im. Kopernika oraz w III Państwowym Gimnazjum i Liceum im. S. Żeromskiego przy ul. Roosevelta (T. Rostworowski TJ, Szerzyć Królestwo. Wspomnienia i dzienniki 1939-1972, wybór i pracowanie O. Tadeusz Pronobis TJ i Stanisław Jan Rostworowski, Warszawa 2004, s. 152-153)

\section{6 lutego 1945, wtorek}

1. W prasie:

1.1. zreferowana treść rozmowy o osiągnięciach i planach filmowców:

W najbliższym okresie rocznym ukażą się filmy o Koperniku, Marii Curie-Skłodowskiej, polskim chłopie, wreszcie film o walce Armii Ludowej z terrorem i okupacją hitlerowską. Te perspektywy, te zamierzenia i podjęte już prace zapoczątkują erę polskiego, naprawdę narodowego filmu. Tradycje Dodków i Bodków są niesmacznym wspomnieniem przeszłości. Film polski będzie odzwierciedlał dzieje narodu, jego walkę i jego codzienność. (Film będzie odzwierciedlat dzieje narodu. Zdjęcia z powstania warszawskiego. 
Operator filmowy na polu walki. Zamierzenia na przyszłość. Rozmowa z mjr.

Aleksandrem Fordem, GL 1945, nr 30 [69], s. 4)

1.2. fraszka Na ostatnia mowe Hitlera, sygnowana podpisem „Poldino" (GL 1945, nr 30 [69], s. 3):

Dawniej - bywało - drży stratosfera,

Kiedy baryton huczał Führera,

I na Europę blady strach padał,

Kiedy ten wściekły brytan ujadał,

A dzisiaj - cóż za metamorfoza!

Jaki łagodny, jaka mimoza!

To już nie Hitler, ale hitlerek,

To już nie brytan, ale ratlerek.

To już nie mowa, to cienki świergot,

Kiedy z pomocą ma przyjść sam Herr Got.

Lecz święty Boże nic nie pomoże -

Dobijem bestię w jej własnej norze.

\section{7 lutego 1945, środa}

1. Konferencja poświęcona organizacji nowej uczelni akademickiej. Postęp prac relacjonują prof. Teodor Vieweger, rektor przedwojennej Wolnej Wszechnicy Polskiej, oraz prof. Bolesław Wilanowski. (Organizacja Uniwersytetu w Łodzi, DŁ 1945, nr 10, s. 4)

2. W prasie:

2.1. informacja o uruchomieniu biblioteki Wojewódzkiego Urzędu Informacji i Propagandy

Wojewódzki Urząd Informacji i Propagandy utworzył Bibliotekę Narodową $\mathrm{w}$ gmachu własnym przy ulicy Traugutta 74. Zarząd zwraca się do społeczeństwa łódzkiego z apelem o składanie do jego dyspozycji książek polskich. (Biblioteka Wojewódzkiego Urzędu Informacji i Propagandy, DŁ 1945, nr 6, s. 4)

2.2. syntetyczny artykuł nt. odradzającej się prasy, m.in. o roli ośrodka łódzkiego

W ostatnich dniach na świeżo oswobodzonych - od hitlerowskich oprawców - ziemiach zaczynają się ukazywać nowe pisma. Powstały one już w Krakowie i w Łodzi, a niedługo zaczną się ukazywać w Katowicach i w Częstochowie. Szereg najpoważniejszych pism przenosi się już w bieżącym tygodniu z Lublina do Łodzi, która - po zupełnym zniszczeniu Warszawy - będzie stanowiła przez szereg miesięcy centrum nie tylko przemysłu, ale i pracy dziennikarskiej. (Prasa na wyzwolonych terenach, DE 1945 , nr 6, s. 2) 


\section{3. informacja o funkcjonowaniu łódzkiej rozgłośni radiowej}

Wystarczy przejść się ulicą Piotrkowską, aby stwierdzić olbrzymie zainteresowanie społeczeństwa - radiem. Zarówno nadawane przez głośniki komunikaty wojenne i polityczne, jak muzyka polska mają stale liczne rzesze słuchaczy. Tłumy ludzi oblegają megafony. Mróz i słota nie stoją na przeszkodzie słuchania muzyki polskiej. Ludność Łodzi z wielkim entuzjazmem powitała rozpoczęcie działalności polskiego radia. W najbliższym czasie rozgłośnia łódzka Polskiego Radia rozmieści głośniki uliczne na ul. Piotrkowskiej do Górnego Rynku. W dalszym ciągu będą radiofonizowane także inne ulice oraz dzielnice robotnicze, kluby, kawiarnie, sale zebrań, szpitale wojskowe i cywilne, świetlice itd. [...] Radiostacje w Warszawie i Łodzi będą z sobą ściśle pracowały drogą obopólnej wymiany programów. Łódź będzie w tym wypadku odgrywała pierwszorzędną rolę, ponieważ do niej, jako do najmniej zniszczonego miasta w Polsce, będą ściągały wybitne osobistości z życia artystycznego i kulturalnego. (Polskie Radio w Łodzi, DŁ 1945, nr 6, s. 4)

\section{4. notatka o nowojorskiej inicjatywie Jana Kiepury}

Jan Kiepura oświadczył przedstawicielom prasy, że uczyni wszystko, co w jego mocy, by jak najbardziej przyśpieszyć transporty pomocy dla Polski. Wyzwolenie Polski nakłada bowiem na każdego Polaka, gdziekolwiek się on znajduje, obowiązek okazania umęczonej ludności jak najszybszej pomocy. (Jan Kiepura o pomocy dla Polski, GL 1945, nr 31 [70], s. 3)

2.5. artykuł zawierający m.in. informacje o działaniach zmierzających do uruchomienia $\mathrm{w}$ mieście pierwszych po wojnie placówek teatralnych

Dobiega końca organizowanie teatru Wojska Polskiego przy ul. Cegielnianej 179. Uruchomienie teatrów staje się zadaniem wyjątkowo trudnym, ponieważ Niemcy zrabowali urządzenia techniczne i sprzęt sceniczny. Czego nie zdołali wywieźć, zniszczyli. Liczni wybitni aktorzy sceny łódzkiej, jak Śleciński, Skwarska, Szydłowska, Chojnacka i inni, którzy wskutek szalejącego w Łodzi terroru, zmuszeni byli opuścić miasto, wracają obecnie, by stanąć do pracy. (Odradza się życie kulturalne Łodzi, GL 1945, nr 31 [70], s. 4)

\section{nie później niż 8 lutego 1945, czwartek}

1. Minister Wincenty Rzymowski powiadamia listownie wiceministra Jana Karola Wendego o dotacji dla Teatru Wojska Polskiego.

Ważyk podjął czterdzieści tysięcy złotych zapomogi dla Teatru Wojska.

(J. K. Wende, Ta ziemia od innych droższa..., Warszawa 1981, s. 262) 


\section{8 lutego 1945, czwartek}

1. W prasie:

1.1. skrótowa relacja $\mathrm{z}$ pierwszego koncertu orkiestry symfonicznej (Koncert orkiestry symfonicznej, DŁ 1945, nr 7, s. 4)

1.2. informacja o organizowaniu instytucji oświatowych

Łódź szybko rozbudowuje szkolnictwo wszelkich typów. Organizuje się obecnie uniwersytet w Łodzi. Pracami przygotowawczymi kieruje prof. Wilamowski [właśc. Wilanowski]. (Oświata w Łodzi, DŁ 1945, nr 7, s. 4)

1.3. relacja z rozmowy z prof. Bolesławem Wilanowskim - zapowiedź otwarcia w marcu 16-wydziałowego uniwersytetu w Łodzi

Gdy tylko łapa okupanta opadła, rozbita potężną prawicą Armii Czerwonej, poprzez niezastygłe jeszcze pola bitew spieszyliśmy do największego polskiego miasta pracy - Łodzi, by tu wspólnym wysiłkiem powołać do życia tak potrzebną Łodzi i Polsce placówkę. (Otwarcie uniwersytetu w Łodzi nastąpi już w marcu. Uniwersytet łódzki będzie miat 16 wydziałów. Prace organizacyjne sa w petnym toku, GL 1945, nr 32 [71], s. 4)

\section{4. informacja o aktywności środowiska teatralnego}

Do pracy nad krzewieniem kultury słowa polskiego w demokratycznej Łodzi, wierny tradycjom tego miasta staje teatr. W najbliższym czasie Łódź będzie miała swoje stałe dwa teatry. [...] Teatr Łodzi, miasta bojowego proletariatu polskiego, będzie służył ludowi, będzie teatrem dla mas. Organizatorzy teatru łódzkiego: wybitna aktorka łódzka Jadwiga Chojnacka, znany reżyser łódzki Henryk Szletyński postawili sobie za zadanie nie tylko odnowić najlepsze tradycje teatru polskiego, ale i związać teatr z nowym życiem, z nową rzeczywistością nowej demokratycznej Polski. (M. Stefańczyk, Powstają 2 teatry w Łodzi, GL 1945, nr 32 [71], s. 4)

1.5. artykuły wymierzone we władze polskie na uchodźstwie oraz w jej krajowe ekspozytury: (1) Z. K., Pan "prezydent” [o Wł. Raczkiewiczu] (DE 1945, nr 7, s. 2); (2) Florian Włodarkiewicz, Drogi i bezdroża polskiej reakcji [m.in. sowiecka wykładnia masakry katyńskiej] (DŁ 1945, nr 7, s. 3)

\section{9 lutego 1945, piątek}

1. Przebywający z wizytą w Łodzi płk. Stefan Matuszewski, minister informacji i propagandy z tzw. Rządu Tymczasowego RP, przeprowadza kontrolę funkcjonowania mediów oraz wygłasza przemówienie przed mikrofonem Polskiego Radia Łódź. (Minister Matuszewski w Łodzi, DŁ 1945, nr 9, s. 3) 
Zewrzyjmy mocniej szeregi - na ostatnim etapie walki o Polskę niepodległą, stańmy wszyscy jak jeden mąż do wielkiego dzieła odbudowy państwa!

Jesteśmy pewni, że Łódź - mająca tak piękne tradycje walki o niepodległość, postęp i demokrację - zajmie pionierską pozycję w tej wielkiej, podjętej przez nas pracy. (Przemówienie przez radio Ministra Informacji i Propagandy tow. St. Matuszewskiego, R 1945, nr 33 [63], s. 2)

2. Henryk Szletyński zostaje powołany na stanowisko dyrektora Teatru Miejskiego.

Jak nas informują Tymczasowy Prezydent miasta Łodzi mianował w dniu wczorajszym dyrektorem Teatru Miejskiego w Łodzi znanego na terenie naszego miasta aktora i reżysera ob. Henryka Szletyńskiego. Dyrektor Szletyński po pięcioletniej przerwie objął kierownictwo Teatru Miejskiego i przystąpił już do prac organizacyjnych. Jedną z najważniejszych kwestii jest obecnie odzyskanie wywiezionego przez okupanta majątku teatralnego, skompletowanie zespołu artystycznego, technicznego i administracyjnego. W planie prac zakrojonych na szeroką skalę przewiduje się również uruchomienie studia. (Szletyński dyrektorem Teatru Miejskiego, DE 1945 , nr 9, s. 3)

3. W prasie:

3.1. w artykuł zawierający punktową charakterystykę miejskiego życia kulturalnego (przede wszystkim sytuacji teatrów) w pierwszych tygodniach po zakończeniu okupacji niemieckiej

Przy Zarządzie Miejskim powstał Wydział Kultury i Sztuki, pod kierownictwem ob. Jadwigi Mijalowej. Rozwinął on swą działalność, skupiając rozproszonych po całej Polsce artystów malarzy i rzeźbiarzy, literatów, muzyków i aktorów. Wydział ochrony zabytków kultury pod kierownictwem ob. Chwalisława Zielińskiego, zajął się zabezpieczeniem muzeów, odnalezieniem dzieł wartościowych znajdujących się w prywatnych rękach bądź też w urzędach niemieckich. Dotychczas udało się odnaleźć kilka egzemplarzy naszych mistrzów pędzla, jak Matejki, Wyczółkowskiego, Gierymskiego, Malczewskiego, Hofmana i innych. Na terenie Łodzi został powołany do zorganizowania teatrów znany aktor i reżyser Szletyński. W najbliższym czasie zostaną otwarte dwa teatry. Rozproszeni po całej Polsce aktorzy wracają do Łodzi.

Napawa nas troską fakt, że z 1500 aktorów sprzed wojny zostało zaledwie 250 , a z tego jeszcze $20 \%$ jest niezdolnych do pracy. I w tej dziedzinie Niemcy dokonali wielkiego spustoszenia. Codziennie jednak przybywają aktorzy i reżyserzy z innych miast - by współpracować w organizowaniu życia artystycznego Łodzi. Ze znanych łódzkiej publiczności aktorów znaleźli się: p.p. Chojnacka, Gosławska, Skrzydłowska. Z nowoprzybyłych zasługuje na szczególną uwagę młody reżyser, Lencz, którego pracę wkrótce będziemy mogli ocenić. 
Wydział Kultury i Sztuki planuje w jak najkrótszym czasie otwarcie szkoły artystycznej, szkoły przemysłu artystycznego, zakładu muzycznego dla dzieci i - o ile warunki techniczne pozwolą na to - także konserwatorium. (Z życia kulturalnego Łodzi, DŁ 1945, nr 8, s. 4)

3.2. artykuł o literackim obliczu „polskiej reakcji” (m.in. o Goetlu, Skiwskim i Burdeckim)

Dość długo szukać musiał okupant w cuchnących zakamarkach reakcji polskiej, by znaleźć takich, którzy chcieliby jawnie wystąpić w charakterze chwalców „nowego ładu w Europie”, „ładu” Majdanka, Katynia i Oświęcimia. Jednak znalazł. Na apel do „rozsądku i trzeźwości politycznej” stawili się panowie Ferdynand Goetel, Jan Emil Skiwski, Feliks Burdecki, Stanisław Kuszelewski i trochę pomniejszego plugastwa, występującego przeważnie anonimowo. Obok oficjalnych gadzinówek ukazały się różne „Przełomy”, "Strażnice” itp. szmaty, które z pobudzającą do śmiechu nieudolnością starały się ukryć ośle uszy goebbelsowskiej sztancy.

Wpływ tej garstki wyrodków na świadomość narodu był tak dalece żaden, znaczenie ich zdradziecko-prowokatorskiej akcji propagandowej w stosunku do ogólnonarodowej walki wyzwoleńczej było tak dalece znikome, że być może, nie wartoby było w ogóle zajmować się tą zgnilizną, gdyby nie pewien istotny szczegół. Przecież tu pachnie „ozonem”. Tak jest, tu cuchnie na całego „ozonem”. Skiwscy, Burdeccy, Goetlowie to kwiatuszki z ozonowskiej łąki. Wykarmiła je i wyhodowała epoka Rydzów, Koców, Becków i oni jawnie sprzedając swój naród pozostali niewątpliwie wierni nauce swych mistrzów i mocodawców z obozu sanacji. Reakcja polska, nie chcąc się ostatecznie pogrzebać w oczach narodu, nie mogła jawnie przejść na stronę okupanta. Wysyłając jednak Skiwskich, Goetlów, Burdeckich itp. na służbę do biur Goebbelsa, tak jak wysyłała „ZŻbików”, ,"Bohunów” itp. na służbę do sztabów Himmlera, reakcja usiłowała wybadać, jaki oddźwięk znajduje w narodzie polityka Quislingów, usiłowała przygotować sobie grunt dla takiej polityki. I tego jej nie zapomni naród polski.

Treścią „pracy” pp. Skiwskich itp. było plugawienie mordowanych w Oświęcimiu, na Majdanku, w Katyniu, Gross Rosen, Oranienburgu, Dachau i tylu innych, niezliczonych fabrykach śmierci. Usprawiedliwianie hulającego bestialstwa. (Polscy pupile Goebbelsa, GL 1945, nr 33 [72], s. 3)

\section{0 lutego 1945, sobota}

1. W prasie:

1.1. ogłoszenie dotyczące organizowania się w Łodzi państwowego uniwersytetu

Wzywa się profesorów i docentów do natychmiastowego zgłoszenia się u delegata Departamentu Szkół Wyższych Ministerstwa Oświaty, Łódź, Grand-Hotel, p. 426, prof. dr N. Łubnicki. Rejestracja profesorów, docentów, 
asystentów i pomocniczych sił naukowych odbywa się w Kuratorium Okręgu Szkolnego Łódzkiego, Łódź, ul. Cegielniana 157, I piętro, pok. 12 w godz. 8-15. (O nowy Uniwersytet Łódzki, DŁ 1945, nr 9, s. 4)

\section{2. wezwanie do odtwarzania księgozbiorów bibliotecznych}

Wydział Oświaty i Kultury Zarządu Miejskiego w Łodzi (ul. Piotrkowska 37) zwraca się z gorącą prośbą do wszystkich obywateli miasta, by ratowali od dalszego zniszczenia resztki ocalałych książek polskich. Chodzi w pierwszym rzędzie o zwrot wypożyczonych w swoim czasie książek z Biblioteki Publicznej (ul. Andrzeja 14), Miejskich Wypożyczalni Książek dla dorosłych, Miejskich Wypożyczalni Książek dla dzieci i młodzieży. Książki te należy zwracać do Miejskiej Biblioteki Publicznej (ul. Andrzeja 14). Wszelkie inne książki z prywatnych i społecznych bibliotek, wypożyczone przed wojną, a przechowane dotąd, należy również składać w Miejskiej Bibliotece Publicznej [...]. Każda zmarnowana książka polska to niepowetowana strata! Ratujmy wszyscy przed zniszczeniem książki polskie, zbierajmy je skwapliwie i składajmy w Miejskiej Bibliotece Publicznej. (Ratujmy książę polska, DŁ 1945, nr 9, s. 4)

\section{1 lutego 1945, niedziela}

1. Premierowy spektakl teatralny w powojennej Łodzi - Radcy pana radcy $\mathrm{M}$. Bałuckiego.

Z powodu radosnych uroczystości oswobodzenia m. Łodzi spod okupacji niemieckiej, pierwszy raz ze sceny zabrzmi słowo polskie. W niedzielę 11 lutego o godz. 4-ej po poł. w sali „Śpiewaków”, ul. 11 Listopada, odegrana będzie komedia w 3-ch aktach Michała Bałuckiego RADCY PANA RADCY osoby: Piotr Dziszewski - Stanisław Śliwiński, Ewa, jego żona - Pola Śliwińska, Helena, ich córka - Barbara Gilewska, Eufrozyna - Antonina Dunajewska, Zdzisław - Roman Wójtowicz, Karol - Witold Trocer, Jan, służący, Karol Żelazko. Reżyser, por. Śliwiński. Wstęp tylko za zaproszeniami. Dla publiczności cywilnej odbywają się przedstawienia codziennie od poniedziałku [12 lutego] od godz. 12 po poł. (Teatr Dramatyczny Armii, DE 1945, nr 8, s. 4)

2. Pierwszy wydany w Łodzi numer „Robotnika”, dziennika koncesjonowanej Polskiej Partii Socjalistycznej Edwarda Osóbki-Morawskiego. Wcześniejsze numery gazety ukazywały się w Lublinie.

Dziś odbiliśmy w Łodzi, w wyzwolonej Łodzi, organ centralny naszej Partii - „Robotnika”. Wraz z podmuchem wolności, pogromem hitleryzmu, z zatknięciem sztandarów zwycięstwa w stolicy polskiego proletariatu, równocześnie z oswobodzeniem starej kuźni socjalistycznej - poszła w ruch maszyna rotacyjna, która codziennie wyrzucać będzie dziesiątki tysięcy egzemplarzy drukowanego socjalistycznego słowa. [...] Kiedy 
nieznane w dziejach, bezprzykładne, wyrafinowane okrucieństwo zbirów hitlerowskich pozostawiło tylko gruzy bohaterskiej Warszawy - kiedy na świętych ruinach męczeńskiej stolicy nie można było jeszcze stworzyć warunków pracy dla prasy robotniczej, wybraliśmy czerwoną Łódź. (Artur Karaczewski, [nota o przenosinach redakcji „Robotnika” do Łodzi] R 1945, nr 33 [63], s. 1)

3. Defilada wojskowa przed siedzibą Zarządu Miejskiego (ul. Piotrkowska 104)

4. W prasie:

4.1. artykuł informacyjny nt. postępów w organizacji szkół

W Kuratorium Szkolnym zostały zorganizowane wydziały: szkół powszechnych, szkół średnich ogólnokształcących, szkół zawodowych, zakładów kształcenia nauczycieli, oświaty dorosłych i wydział ogólny. W szeregu powiatów obejmują pracę delegowani przez Kuratorium inspektorzy szkolni. Powołuje się do życia zakłady kształcenia nauczycieli (pedagogium i liceum pedagogiczne). Dążeniem władz szkolnych jest umożliwienie wstępu do szkół w pierwszym rzędzie młodzieży robotniczej, chłopskiej i inteligencji pracującej. W tym celu będą organizowane internaty przy szkołach. Poza normalnymi zakładami dla młodzieży w wieku szkolnym, powstaną również szkoły powszechne, gimnazja i licea dla dorosłych. Władze szkolne liczą na poparcie ze strony terenowych Rad Narodowych, ze strony rodziców uczącej się młodzieży i w ogóle ze strony całego społeczeństwa przy odbudowie polskiej szkoły, na którą młodzież nasza tak długo czekała. Pomoc ta wyrazić się winna w remontowaniu lokali, urządzaniu szkól, zaopatrywaniu w sprzęt, biblioteki, książki, podręczniki, warsztaty i maszyny (dla szkół zawodowych). (Prace w zakresie szkolnictwa postępuja, DŁ 1945, nr 10, s. 3)

\section{2 lutego 1945, poniedziałek}

1. Teatr Wojska Polskiego daje pierwszy spektakl otwarty dla publiczności miejskiej - Radcy pana radcy M. Bałuckiego. (Teatr Dramatyczny Armii, DŁ 1945, nr 8, s. 4)

2. Po ukazaniu się 10. numeru wstrzymany zostaje druk „Dziennika Łódzkiego". Wydawanie gazety zostanie wznowione w lipcu 1945 r.

\section{nie wcześniej niż 12 lutego 1945, poniedziałek}

1. Na polecenie Jerzego Borejszy, który udziela Czytelnikowskiej ciężarówki, Ryszard Matuszewski przywozi do Łodzi Zofię Nałkowską i Polę Gojawiczyńską, dla których przygotowano mieszkania w kamienicy literatów przy ul. Bandurskiego 8 (obecnie al. Mickiewicza) 
[...] gdzieś pomiędzy władzami ZLP [właśc. ZZLP] a rozwijającym energiczną działalność organizacyjną prezesem „Czytelnika” Jerzym Borejszą [...] zapadła decyzja, by dwa reprezentacyjne 4-pokojowe lokale w domu przy Bandurskiego przydzielić Zofii Nałkowskiej i Poli Gojawiczyńskiej. [...] Ponieważ zabiegałem wtedy o ciężarówkę, by przewieźć swoje ocalałe po Powstaniu resztki księgozbioru ze zniszczonego mieszkania na Żoliborzu do tego, w którym wówczas mieszkałem w Łodzi, Borejsza oświadczył, że da mi ciężarówkę, ale w drodze powrotnej mam zabrać i przywieźć do Łodzi obie pisarki. [...] Stan techniczny ciężarówki okazał się fatalny, na przestrzeni kilkudziesięciu kilometrów dzielących Adamowiznę od Łodzi trzykrotnie wysiadały opony i za ostatnim razem, już na przedmieściach Łodzi, późnym wieczorem, musieliśmy zrezygnować z dalszej jazdy [...] i prosić o prowizoryczny nocleg $\mathrm{w}$ jednym $\mathrm{z}$ przydrożnych domostw. (fragm. relacji Ryszarda Matuszewskiego, przytoczonej przez H. Kirchner w przypisie do: Z. Nałkowska, Dzienniki, t. 6: 1945-1954. Część 1 [1945-1948], opracowanie, wstęp i komentarz H. Kirchner, Warszawa 2000, s. 45)

\section{3 lutego 1945, wtorek}

1. Konstytuuje się Oddział Łódzki Związku Zawodowego Literatów Polskich.

We wtorek, 13 b.m. odbędzie się zebranie literatów w celu zorganizowania oddziału łódzkiego Związku Zawodowego Literatów Polskich. Zebranie odbędzie się o godzinie $15 \mathrm{w}$ domu przy Al. Kościuszki 158 (róg Bandurskiego), przydzielonym Związkowi Literatów przez Rząd. (Zebranie literatów w Łodzi, RZ 1945, nr 42, s. 4)

W dniu 13 II 1945 ukonstytuował się Oddział Łódzki ZZLP: prezes Z. Nałkowska, wiceprezes - J. Brzechwa, członkowie Zarządu - J. Huszcza i J. Minkiewicz. (cyt. za: Z. Nałkowska, Dzienniki, t. 6: 1945-1954. Część 1 [1945-1948], opracowanie, wstęp i komentarz H. Kirchner, Warszawa 2000, s. 47 - przypis autorstwa Hanny Kirchner)

2. Ukazuje się pierwszy łódzki numer dziennika "Rzeczpospolita” (1945, nr 42 [186]). Stopka redakcyjna: „Adres Redakcji i Administracji: Łódź, Piotrkowska 96. Drukowano w Zakładach Graficznych w Łodzi, Piotrkowska 86. Wydawca : Spółdzielnia »Czytelnik«". W numerze m.in. podwójna relacja z niedawnej defilady wojskowej w Łodzi.

Dzień jedenasty lutego stanowić będzie dla Łodzi niewątpliwie historyczną datę. Po długich latach najokrutniejszego terroru, po długiej i ponurej nocy niewoli tłumy wyległy na ulicę, twardy krok polskich oddziałów wojskowych radośnie rozbrzmiewał na bruku. [...]

Ze wszystkich dzielnic, ze wszystkich domów spływają tutaj gromady ludzkie, aby zobaczyć, aby nacieszyć się widokiem polskiego munduru, 
aby zobaczyć, aby nacieszyć się błyskiem szabel polskich, aby wchłonąć w duszę wspaniały obraz pierwszej na ulicach Łodzi defilady. [...]

Uderzają o nagi bruk wolnego miasta słowa, które nie tylko w okresie okupacji niemieckiej, ale i na długo przed tragicznym wrześniem były wzbronione: „Niech żyje sojusznicza Armia Czerwona”! „Niech żyje Marszałek Stalin”! „Niech żyje generał broni Michał Rola-Żymierski”! „Niech żyje wolna, niepodległa Polska demokratyczna”. (S. Babisiak, Defilada Wojska Polskiego, RZ 1945, nr 42 [186], s. 3)

Niedzielna defilada Wojska Polskiego stała się wzruszającą manifestacją społeczeństwa łódzkiego na cześć Armii. Dziesiątki tysięcy ludzi wyszły na ulicę, by powitać swego żołnierza ponownie maszerującego ulicami miasta. [...]

Było coś głęboko wzruszającego w zespoleniu żołnierza z narodem. Małe dzieci polskie snujące się między szeregami i oddające maszerującym oddziałom kwiaty, kobiety zastępujące drogę, by doręczyć im upominki, mężczyźni wiwatujący wzdłuż całej drogi na cześć Armii, jej wodzów i kierowników nawy państwowej - był to Naród Polski. Łączył się on z żołnierzem w więź nierozerwalną - na zawsze. (S. Ziemak, Dzień stońca i wzruszenia, RZ 1945, nr 42 [186], s. 3)

\section{4 lutego 1945, środa}

1. W „Rzeczpospolitej” informacja o otwartym dla publiczności cyklicznym „kwadransie literackim”.

Staraniem Wydziału Kultury i Sztuki odbywa się codziennie o godz. 5-ej p.p. w Domu Kultury Robotniczej przy ulicy Gdańskiej 32 Kwadrans literacki. („Kwadrans Literacki”, RZ 1945, nr 43 [187], s. 4)

\section{7 lutego 1945, sobota}

1. Rozpoczyna się pierwsza Wojewódzka Konferencja Polskiej Partii Robotniczej woj. łódzkiego; uczestniczą w niej i głos zabierają m.in. Ignacy Loga-Sowiński (sekretarz Komitetu Wojewódzkiego PPR), Wiesław Gomułka (sekretarz generalny Komitetu Centralnego PPR), Aleksander Burski (drugi sekretarz KW PPR), Władysław Nieśmiałek (sekretarz Komitetu Miejskiego PPR w Łodzi) oraz Kazimierz Mijal (pełnomocnik Rządu Tymczasowego). (Konferencja wojewódzka PPR rozpoczęta się wczoraj w Łodzi przy udziale 550 delegatów, GL 1945, nr 41 [80], s. 3)

2. W prasie:

2.1. informacja o pracach nad powołaniem do życia filharmonii

Przypadkowo dowiedzieliśmy się o przyjeździe do Łodzi Zdzisława Górzyńskiego. Ma tutaj zorganizować Filharmonię. Pamiętamy go dobrze 
sprzed wojny, z Małej Orkiestry Polskiego Radia. Nie wiedzieliśmy przez cały czas okupacji, co się z Górzyńskim dzieje.

Więc jest w Łodzi.

Górzyński jest z pochodzenia krakowianinem i uczniem Władysława Żeleńskiego. Kończył konserwatorium w Krakowie i Wiedniu. W tym samym Wiedniu dyrygował po raz pierwszy graną zagranicą Halka Moniuszki. Było to w Volksoperze w r. 1926.

W kraju zajmował kolejno stanowisk kapelmistrza Opery warszawskiej i lwowskiej i dyrektora Opery w Katowicach. W Łodzi kierował Filharmonią w latach 1921-23, dojeżdżając z Warszawy. [...]

W tej chwili [ - mówi Górzyński - ] organizuję orkiestrę filharmoniczną, opracowuję partytury, wyszukuję muzyków i instrumenty. Wszędzie napotykam na przyjaźń i niezwykle przychylne ustosunkowanie się do spraw muzyki. Nie ma absolutnie mowy o przyrównywaniu tego, co jest teraz, do stosunków przedwojennych. Zupełnie inne nastawienie władz i poszczególnych ludzi do muzyki i kultury w ogóle. W tych warunkach rzeczywiście można pracować.

- Idzie o powołanie do życia Filharmonii, która by była dobrem kulturalnym jak najszerszych sfer społeczeństwa. W tej dziedzinie jest bardzo wiele do zrobienia. Otworzymy wszystkie wejścia do sal koncertowych dla robotnika i chłopa. Mam w planie również całe serie koncertów objazdowych. - Przecież wreszcie będziemy mieli możność zapoznać z ogólnoludzkim dorobkiem kulturalnym w dziedzinie muzyki tych wszystkich, którzy tego pragną, i tych, którzy nawet do dziś nie zdają sobie sprawy z ogromu piękna muzyki, bo nie mieli elementarnych możliwości choćby tylko słuchania.

Życzymy Zdzisławowi Górzyńskiemu pomyślnej i owocnej pracy i żegnamy go, ożywionego niezwykle i pełnego entuzjazmu. (W Łodzi powstaje Filharmionia. [Wywiad ze Zdzistawem Górzyńskim], GL 1945, nr 40, s. 4)

\section{8 lutego 1945, niedziela}

\section{W prasie:}

1.1. artykuł na temat powrotu na plac Wolności pomnika Tadeusza Kościuszki, ważny dla oceny propagandowej strategii komunistów

Niejeden z nas, gdy spojrzy na Plac Wolności, wspomni z pewnością, że pięć i pół lat temu stał na tym Placu pomnik Tadeusza Kościuszki. Pomnik, który wystawiła robotnicza Łódź - pomnik, który był zespoleniem naszych serc z ideą wodza - twórcy Armii Ludowej. On, wódz, ubrany w sukmanę krakowską, przysięgał ludowi, że będzie bronił jego praw i oddał krew swej świętej ziemi polskiej. Stworzył armię z ludu - z włościan i mieszczaństwa, dał im nowe hasła i nowe prawa. Zrobił przewrót, w ówczesnej organizacji wojskowej, przystępując do budowy armii masowej, armii, która służyć miała sprawom narodu. [...]

Gdy Niemcy wkroczyli do Łodzi, pomnik stał, a wysoko z jego szczytu spoglądały dumnie oczy wodza, który z pogardą patrzył na 
plugawstwo [sic!] niemieckie. Dłoń jego, oparta na szabli, chciała jak gdyby wyrwać ją z pochwy, by jeszcze raz stanąć w obronie wolności. Patrzyli nieśmiało niemieccy żołdacy $\mathrm{w}$ tę twarz. I chociaż zwyciężyli, nie byli pewni zwycięstwa. Nie mogli nazwać Łodzi „Litzmannstadt”, póki stał on, Kościuszko. I skrycie, pod osłoną nocy, żeby ukryć swój czyn zbrodniczy, wysadzili dynamitem pomnik bojownika wolności. [...]

I od tej chwili, z „czystym sumieniem” nazwali Plac Wolności - „Deutschland Platz”.

I nagle, po kilkunastu latach gnębienia i niemczenia Łodzi, słyszymy, że gdzieś daleko w Rosji tworzą się pułki polskie, pod nazwą dywizji im. Tadeusza Kościuszki. Odżyła w nas nadzieja wolności, Kościuszko stanął przed nami. Jego imię, sztandar i myśl szła do nas znad Oki, jego czyn sprzed laty [sic!] niósł nam teraz wolność.

Przy boku Armii Czerwonej szedł żołnierz polski spod jego znaku, walczyć o wolność ludów. Znów z żołnierzem polskim poczęło imię jego przebiegać świat. I dziś na placu, tam gdzie stał pomnik, spoczywają zwłoki rosyjskich żołnierzy i tam stanie pomnik ku chwale bojowników wolności. Znów stanie na placu Kościuszko. Jego duch stał się drogowskazem, jego walka trwa w czynach partyzanta i żołnierza polskiego, jego słowa „Za waszą wolność i naszą" - my właśnie wcielamy w życie. (T. S. Nowak, Pomnik Kościuszki na Placu Wolności, GL 1945, nr 41 [80], s. 3)

1.2. artykuł informujący o rzekomo powszechnym poparciu postanowień konferencji jałtańskiej

Onegdaj na terenie miasta Łodzi odbyło się 5 wielki zgromadzeń [...]. Na wiecach, do wypełniającej po brzegi sale ludności przemawiali przedstawiciele PPR, PPS, Stronnictwa Ludowego, Stronnictwa Demokratycznego, Okręgowej Rady Związków Zawodowych, omawiając szczegółowo wyniki Konferencji Trzech.

Po przemówieniach przyjęte zostały jednomyślnie rezolucje o następującym brzmieniu:

„Zgromadzeni na zebraniu poświęconym sprawie wyników Konferencji Trzech witają uchwały konferencji świadczące o bliskim ostatecznym zwycięstwie krajów demokratycznych nad wrogiem ludzkości - Niemcami hitlerowskimi. Zwycięstwo to narody Europy zawdzięczają w pierwszym rzędzie Armii Czerwonej. Uchwały konferencji są świadectwem wzmocnienia jedności krajów demokratycznych w walce nie tylko o rozgromienie Niemiec hitlerowskich, ale również w walce o przyszły trwały pokój, w walce o zwycięstwo demokracji nad faszyzmem.

[...] Wszelkie rachuby reakcyjnej kliki emigracyjnej, która nazwała się rządem, która chciała zagarnąć władzę w Polsce, która dążyła do rozpalenia wojny domowej, która wysługiwała się hitleryzmowi, skończyły się sromotnym bankructwem.

Uchwały konferencji, przechodzące do porządku dziennego nad pretensjami kliki londyńskich bankrutów emigracyjnych, świadczą o tym, że opinia międzynarodowa, że mocarstwa koalicji antyhitlerowskiej 
uświadamiają sobie, że klika ta nie reprezentuje narodu, że naród nie uznaje jej i potępia jej zdradziecką robotę.

Jednocześnie zgromadzeni wyrażają swoją wolę, aby przyszły nowy Rząd Tymczasowy Jedności Narodowej kontynuował politykę demokratyczną PKWN, wyrażaną w manifeście lipcowym, aby w dalszym ciągu kontynuował wielkie dzieło spełnienia odwiecznych marzeń chłopstwa polskiego - dzieło natychmiastowego przeprowadzenia reformy rolnej, uchwalił prawa demokratyczne, zdobyte przez naród, kontynuował nieubłaganą walkę przeciw reakcji polskiej, dążącej do przywrócenia w Polsce faszystowskich metod rządzenia. [...]". (Eódź robotnicza o Konferencji Krymskiej, GL 1945, nr 41 [80], s. 4)

\section{3 lutego 1945, piątek}

1. Ukazuje się pierwszy łódzki numer dziennika „Polska Zbrojna”. Adres redakcji: ul. Piotrkowska 151. Informacje zawarte w stopce redakcyjnej: „Wydaje Główny Zarz[ąd] Polit[yczno-]Wych[owawczy] W[ojska] P[olskiego]. Odbito w drukarni Spółdzielni »Czytelnik«".

\section{7 lutego 1945, wtorek}

1. B. Bierut i M. Rola-Żymierski odbywają spotkanie z pracownikami łódzkich fabryk.

Robotnicy największych łódzkich zakładów przemysłu włókienniczego dawnej firmy Scheiblera i Grohmana przeżyli [...] niezapomniany dzień: przybyli do nich w odwiedziny Prezydent K. R. N. ob. Bierut oraz Naczelny Dowódca W. P., gen. broni Rola-Żymierski. (Prezydent K.R.N. i Naczelny Dowódca W.P. wśród robotników tódzkich, PZ 1945, nr 29, s. 1)

2. M. Rola-Żymierski dokonuje oficjalnego otwarcia Głównej Księgarni Wojskowej w Łodzi. Towarzyszą mu kapelan oraz szef Wojskowego Instytutu Naukowo-Wydawniczego, ppłk. Ignacy Płażewski.

Ks. kapelan Moskwa poświęcił lokal księgarni, a następnie gen. Rola-Żymierski przeciął biało-czerwoną wstęge [...].

Księgarnia Wojskowa stoi pod względem ilości posiadanych książek o wiele wyżej niż do niedawna. Posiada ona dużo nowych książek z terenów wyzwolonych, przeważnie z Warszawy i Łodzi. Ogólna ilość książek wojskowych wynosi obecnie około 20 tysięcy. Prócz tego jest na składzie dużo książek naukowych w różnych językach oraz książek szkolnych i sportowych. W Łodzi ofiarowano księgarni większą ilość słowników polsko-rosyjskich i rosyjsko-polskich. Na składzie są wojskowe mapy sztabowe. Księgarnia zajmuje się również prenumeratą oraz sprzedażą gazet i czasopism. (J. F., Uroczyste otwarcie Głównej Księgarni Wojskowej, PZ 1945, nr 29, s. 1) 


\section{8 lutego 1945, środa}

1. Wizyta M. Roli-Żymierskiego w siedzibie redakcji „Polski Zbrojnej” w Łodzi.

W dniu wczorajszym Naczelny Dowódca, gen. broni Rola-Żymierski, przybył do redakcji „Polski Zbrojnej”. Naczelny Dowódca interesował się pomieszczeniem redakcji, administracji i drukarni oraz warunkami pracy i bytu oficerów i szeregowych.

Następnie w gronie kolegium redakcyjnego gen. Rola-Żymierski wypowiedział swą opinię o gazecie, udzielił szeregu wskazówek w sprawie organizacji pracy, nakreślił linie wytyczne pracy redakcyjnej oraz interesował się sprawą trudności, hamujących racjonalną pracę redakcji, przyrzekając pomoc w ich usunięciu.

Wizyta Naczelnego Dowódcy i jego żywe zainteresowanie dla pracy redakcji wywarła silne wrażenie wśród zespołu redakcyjnego. (Naczelny Dowódca W.P. w redakcji „Polski Zbrojnej”, PZ 1945, nr 30, s. 1)

\section{luty (?) 1945}

1. Tadeusz i Janusz Drewnowscy przyjeżdżają do Łodzi, gdzie przebywa już ich brat Jerzy, oficer armii polskiej przybyłej z ZSRS. Zamieszkują w mieszkaniu Jerzego przy Bandurskiego 8 (obecnie al. Mickiewicza). Niewiele później przeprowadzają się do poniemieckiej willi na Julianowie. Tadeusz zapisuje się do liceum im. S. Żeromskiego, gdzie zrobi maturę.

Z Krakowa do Łodzi kursowały tylko wojskowe transporty. Władowaliśmy się z Januszem do wagonu towarowego. Podróż ciągnęła się blisko dobę i nieodwołalnie urwała się w Koluszkach. Trwał siarczysty mróz. Jakiś kolejarz przygarnął nas na noc do swojego mieszkania koło stacji. Nazajutrz w Łodzi odszukaliśmy Jerzego na jego kwaterze przy Bandurskiego 8. Wtedy to jeszcze nie był dom literatów, w każdym razie po części kwaterowało tam wojsko.

Rozpatrywaliśmy, kiedy i którędy może wracać nasza matka z Ravensbrück. Postanowiliśmy, że Jerzy jadąc jako korespondent na front zahaczy o Ravensbrück, a Janusz wybierze się do Warszawy, aby na ruinach, wszędzie gdzie mogłaby nas szukać, wypisać nasz adres, którego jeszcze nie mieliśmy. Na gwałt potrzebne nam było mieszkanie. Wkrótce dzięki wojskowym uprawnieniom Jerzego zajęliśmy dół niewielkiej poniemieckiej willi na Julianowie, prawie całkowicie urządzonej, i na dodatek - z obsługą. Zastaliśmy tam bowiem pannę Teresę, młodą Niemkę, która do czasu repatriacji (a wyjazdy Niemców z Łodzi ciągnęły się jakieś dwa lata) zmuszona okolicznościami podjęła się prowadzić nam gospodarstwo.

Zaraz w lutym poszedłem do ostatniej klasy liceum im. Żeromskiego. Byłem w klasie jednym z młodszych. Podczas okupacji młodzież w należącej do Reichu Łodzi nie uczyła się; mnie jakimś fuksem, mimo 
moich burzliwych przypadków okupacyjnych, udało się nie stracić ani jednego roku. Z tego ostatniego skróconego kursu niewiele mi pozostało w pamięci: paru kolegów (Adam Bukowczyk, Zbyszek Filipow i Józek Koprowski) i wspaniała polonistka - Wanda Kwaskowska, której lekcje jeszcze rozpalały moje literackie zainteresowania. (T. Drewnowski, Tyle hałasu - o nic? Wspomnienia, Warszawa 1982, s. 56-58)

1. Pierwszy z dwóch łódzkich koncertów Zespołu Pieśni Tańca i Armii Czerwonej.

1-go i 2-go marca Zespół Pieśni i Tańca Armii Czerwonej da 2 koncerty na rzecz dzieci - sierot po Polakach - ofiarach terroru hitlerowskiego. Koncerty odbędą się w sali Teatru Miejskiego przy ul. Cegielnianej. Przedsprzedaż biletów w kasie Teatru od godz. 11-tej. Początek koncertów o godz. 15-tej czasu miejscowego. (Koncert zespołu Armii Czerwonej w Łodzi, GL 1945, nr 51 [90], s. 4)

2. Otwarcie czytelni dzienników, czasopism i książek w siedzibie Rejonowego Urzędu Informacji i Propagandy przy ul. Krzemienieckiej 16 (Czytelnia, GL 1945, nr 61 [100], s. 4)

3. Ukazuje się pierwszy numer tygodnika „Szpilki” (1945, nr 1). Skład redakcji: Stanisław Jerzy Lec, Leon Pasternak, Jerzy Zaruba; adres redakcji: ul. Piotrkowska 96; wydawca tygodnika: „Czytelnik”. Na drugiej stronie dwa teksty dające wyobrażenie o ideowo-politycznej linii pisma:

3.1. wiersz L. Pasternaka Bruk emigracji: „Spójrzcie - jak się zagranicą taki typ panoszy, / jak się po stolicach emigracji szasta! / Śmigły biegacz z żałosnej zaleszczyckiej szosy / - sławojkowy działacz, znany mistrz w konszachtach. // Gęba pełna Polski! On też nabył patent / na tę schedę jeszcze nie okrytą kirem. / I teraz dyskontuje zlane krwią Westerplatte / ów niedoszły, Polski pomajowej, fuehrer" [fragment]

3.2. artykuł wstępny S. J. Leca

To co zostało z "miazmatów” narodu, ze "szpilkowców”, zebrało się w Łodzi. Nasi adwersarze daleko. Jedni wywiali z ojczyzny na wichrze historii i są dziś wyznawcami filozofii tomistycznej „Pomcia z Londynu”. Innych, co się czołgali przed Niemcami, szkopy przemontowali na swoje czołgi „Ferdynandy”. Ferdynandy Goetle poczołgały się za nimi. A my, „miazmaty" narodu, skrwawiliśmy się obficie w tej świętej krucjacie, po miastach, lasach i obozach ojczyzny. Padł Edward Szymański, padł Tadeusz Hollender, Zuzanna Ginczanka, Leonid Fokszański, Franc Parecki, Leonard Hanin, Allan, Mecenas Wacuś, Reif. W mitrędze wojennej zmarł Światek Karpiński, Siemaszko, Jerzy Kamil Weintraub, Czyściecki i wielu innych. Oto siedzimy tu. Ten przyszedł z Pierwszą Dywizją, ten wrócił z Oflagu, ten z lasu wyszedł z literą AL na sercu. 
4. Na łamach „Polski Zbrojnej” zapis „wrażenia” B. Bieruta z pobytu w Łodzi i Kutnie

Powitanie, jakie mi zgotowała ludność Łodzi i Kutna, bardzo mnie wzruszyło. Kiedy przechodziłem ulicami Łodzi, widać było, że miasto jest już odniemczone. Radosne nastroje uwidoczniły się w żywiołowych licznych demonstracjach ludności, manifestujących pomimo niepogody. Radość jest tym większa, że Łódź znajduje się w tym szczęśliwym położeniu, iż nie została zniszczona. Ludność Łodzi docenia to i nie szczędzi objawów swej przyjaźni dla Czerwonej Armii.

W obydwu uroczystościach, zarówno w Łodzi, jak i w Kutnie, bardzo dobitnie uwidoczniła się łączność miejscowego społeczeństwa z Rządem i Wojskiem Polskim, poza tym niezwykle gorąco i mocno akcentowane były uczucia przyjaźni dla Republik Związku Radzieckiego, miłość do Wojska Polskiego oraz szczery zapał do życia i pracy w demokratycznej Polsce.

Wyjechałem z Łodzi i opuszczam Kutno z mocnym przekonaniem, że między robotniczą Łodzią i mniejszym ośrodkiem robotniczym jak Kutno a władzami demokratycznej Polski zawiązało się i istnieje wzajemne zaufanie i mocna łączność, która jest gwarancją tego, że hasło Rządu „demokracja" głęboko weszło w społeczeństwo. (Prezydent Bierut jest głęboko wzruszony powitaniem, jakie mu zgotowała Łódź i Kutno, PZ 1945, nr 30, s. 1)

\section{2 marca 1945, piątek}

1. Drugi z koncertów Zespołu Pieśni i Tańca Armii Czerwonej w budynku Teatru Miejskiego przy ul. Cegielnianej.

2. W prasie:

2.1. informacja o pracach nad powołaniem do życia łódzkiej wyższej szkoły muzycznej

W Łodzi powstaje obecnie Państwowe Konserwatorium [...]. Kierownictwo zakładu zostało powierzone prof. Kazimierzowi Wiłkomirskiemu, Spośród zaangażowanych już profesorów wymienić należy: Helenę Kijeńską-Dobkiewiczową, A. Wielhorskiego, K. Sikorskiego, B. Wojtowicza. Obsadzanie innych wydziałów trwa. Nauka na wszystkich wydziałach będzie bezpłatna. Egzaminy wstępne odbędą się w najbliższych dniach, rozpoczęcie wykładów nastąpi w ciągu 2 tygodni. (Państwowe Konserwatorium powstaje w Łodzi, GL 1945, nr 52 [91], s. 4)

\section{3-6 marca 1945}

1. Na scenie Teatru Miejskiego przy ul. Cegielnianej „Zespół Artystyczny Armii Polskiej” prezentuje „barwne i wesołe widowisko" pt. Dziś gramy dla cywilów. („Dziś gramy dla cywilów”, PZ 1945, nr 31, s. 4) 


\section{4 marca 1945, niedziela}

1. Zjazdy wojewódzkie koncesjonowanych Polskiej Partii Socjalistycznej, Stronnictwa Ludowego i Związku Młodzieży Wiejskiej „Wici”. Uczestników obrad wita przedstawiciel Armii Czerwonej, generał-major Porfiryj Furt (Furtienko)

W dyskusji na Zjeździe padły ostre słowa przeciw pachołkom sanacyjnym z tzw. „W. R. N.”. Pierwsza wojewódzka konferencja PPS wysłała telegramy hołdownicze do Marszałka Stalina, Prezydenta Krajowej Rady Narodowej ob. Bieruta i do Premiera Rządu Tymczasowego tow. Osóbki-Morawskiego. (Obrady stronnictw politycznych w Łodzi. Wojewódzka Konferencja PPS, GL 1945, nr 55 [94], s. 4)

Obradujący działacze ruchu ludowego wysłali depesze do Marszałka Stalina, do Prezydenta Krajowej Rady Narodowej ob. Bieruta, do Premiera Rządu Rzeczypospolitej ob. Osóbki-Morawskiego, do Naczelnego Dowódcy Wojska Polskiego Generała Roli-Żymierskiego. (Obrady stronnictw politycznych w Łodzi. Wojew. Zjazd Stronnictwa Ludowego, GL 1945, nr 55 [94], s. 4)

2. Uroczysta akademia „ku czci Wojska Polskiego” w sali „Śpiewaków” przy ul. 11 Listopada 21.

Salę szczelnie wypełnili przedstawiciele władz państwowych, samorządowych, organizacyj politycznych, społecznych i kulturalnych oraz reprezentanci Wojska i sojuszniczej Armii Czerwonej. M.in. byli obecni: wojewoda łódzki ob. Kocioł, wojenny komendant m. Łodzi, gen. mjr Furt, szef Wojsk. Instytutu Naukowo-Wydawniczego ppłk. Płażewski, zastępca kwatermistrza W.P. płk. Braun i wielu oficerów tutejszego garnizonu.

Po zagajeniu akademii przez przewodniczącą Tow. Przyj. Żołn., ob. Henrykę Kokoć, ob. Frnaciszek Kokoć wygłosił porywające przemówienie, które zakończył słowami:

"Stwórzmy potężny gmach państwowy, ręce nasze niechaj będą cementem, my wszyscy - jak jedna wielka rodzina, zamieszkała w tym gmachu, wywieśmy na nim sztandar, na którym wypiszmy: »Polska wielka i potężna«. Złączmy się w wysiłku z naszą ukochaną Armią, która ofiarą krwi wespół z braterską Armią Czerwoną wyrąbuje granice Polski na Odrze, Nissie i nad Bałtykiem".

Mówca wzniósł okrzyk na cześć Wojska Polskiego i jego Dowódcy Naczelnego gen. broni Michała Roli-Żymierskiego. Orkiestra odegrała Hymn Narodowy. A po tym zerwała się burza oklasków i okrzyków hołd robotniczej Łodzi dla swojego Wojska. (H., "Złączmy się w wysitku z nasza ukochana Armią!". Akademia ku czci Wojska Polskiego, PZ 1945, nr 34, s. 4)

3. Obchody Dnia Wyzwolenia Szkoły Polskiej. 
W dniu 4 marca, aby dać wyraz zespolonego i solidarnego działania, obchodzić będziemy w Łodzi i na terenie całego województwa radosny i długo oczekiwany Dzień Wyzwolenia Szkoły Polskiej.

Program obchodu w Łodzi jest następujący:

godz. 9 - nabożeństwo w katedrze, złożenie wieńców na miejscu płyty Nieznanego Żołnierza;

godz. 10 - przemarsz ul. Piotrkowską i defilada młodzieży szkolnej przed przedstawicielami władz szkolnych, administracyjnych i wojskowych (ul. Piotrkowska 104);

godz. 11 - złożenie wieńców na grobach poległych żołnierzy radzieckich i polskich o wyzwolenie Łodzi. Przemówienia przedstawicieli władz, rodziców, młodzieży.

O godzinie 13 odbędą się bezpłatne przedstawienia $w$ kinach $i$ teatrach dla młodzieży szkolnej. (Dzień szkoły polskiej będzie obchodzony w Łodzi dnia 4 marca, GL 1945, nr 53 [92], s. 4)

Granatowe płaszcze, granatowe czapki, dziarski równy krok. Odśmiechają się marcowemu słońcu dumną purpurą i złotem sztandary, radośnie śmieją się oczy. Słońce wszędzie - na niebie zajaśniało po dniach niepogody, jakby specjalnie na ten dzień radosny, słońce jest w oczach maszerujących i widzów i słońce jest w duszach. Bo nasza młodzież, nasza przyszłość i nadzieja wyległa tłumnie na ulice Łodzi święcić DZIEŃ WYZWOLENIA SZKOEY POLSKIEJ. [...]

W niedzielę sztandary szkolne święciły dzień odrodzenia. Odrodzenia nie tylko z przeklętej niewoli hitlerowskiej, ale i odrodzenia z dawnych przesądów i przywilejów, kiedy wrota szkół zamknięte były dla dziatwy robotniczej i chłopskiej. [...]

Krzepko dzierżą małe dłonie transparenty.

„Niech żyje Rząd Tymczasowy”.

„Niech żyje przyjaciel Polski, Wielki Stalin”.

„Niech żyje Wojsko Polskie”. (Święto młodzieży szkolnej, GL 1945, nr 55 [94], s. 4)

4. W „Głosie Ludu” entuzjastyczne omówienia:

4.1. programu Zespołu Pieśni i Tańca I Frontu Białoruskiego Armii Czerwonej, na który złożyły się również utwory polskie

Zarówno [...] skecze, jak i pieśni polskie potęgowały wśród audytorium entuzjazm - wyraz wdzięczności społeczeństwa polskiego dla Związku Radzieckiego za jego wkład w odbudowujące się życie kulturalne Polski. (baj., Zespót pieśni i tańca I-go Frontu Białoruskiego, GL 1945, nr 54 [93], s. 4)

\section{2. występów kwartetu smyczkowego i solistów sowieckich}

Występy wybitnych artystów Związku Radzieckiego zbiegły się w Łodzi z uroczystościami na cześć odmaszerowujących na front oddziałów Wojska Polskiego, na które przybyli Prezydent Krajowej Rady 
Narodowej ob. Bolesław Bierut i Naczelny Dowódca Wojska Polskiego gen. broni Michał Rola-Żymierski.

Koncerty Zespołu Radzieckiego wywołały szczery zachwyt wśród mieszkańców robotniczej Łodzi, budząc uczucia najszczerszej sympatii klasy robotniczej w Polsce dla bratniego Narodu Radzieckiego. (Występy artystów radzieckich wywołały szczery zachwyt wśród mieszkańców robotniczej Łodzi, GL 1945, nr 54 [93], s. 4)

5. Na łamach „Polski Zbrojnej” (1945, nr 33, s. 2-3) opowiadanie Stanisława Piętaka Więzień.

\section{6 marca 1945, wtorek}

1. Na łamach „Polski Zbrojnej” relacje z frontu - Janiny Broniewskiej (Żotnierz idzie jak huragan... Rozmowa z Dowództwem 1 Armii Polskiej - gen. Poptawskim i gen. Strażewskim, PZ 1945, nr 34, s. 2) i Tadeusza Jacka Rolickiego (Idziemy naprzód na S., PZ 1945, nr 34, s. 2)

\section{7 marca 1945, środa}

1. Pierwsze plenarne posiedzenie Miejskiej Rady Narodowej. Na prezydenta miasta zostaje wybrany Kazimierz Mijal (PPR)

[...] porządek dzienny m.in. obejmuje: 1) sprawozdanie z działalności Tymczasowego Zarządu Miejskiego, 2) wybór prezydium Miejskiej Rady Narodowej, 3) wybór kandydatów na Prezydenta miasta i 3 wiceprezydentów, 4) wybór 5 posłów do Krajowej Rady Narodowej.

Posiedzenie odbędzie się w sali Teatru Miejskiego, ul. Cegielniana 17, punktualnie o godz. 9-ej. (I Zebranie Miejskiej Rady Narodowej m Łodzi, GL 1945, nr 54 [93], s. 4)

W środę 7 b. m. odbyło się w sali Teatru Miejskiego inauguracyjne posiedzenie Miejskiej Rady Narodowej. Przewodniczący zebrania płk. Loga-Sowiński w przemówieniu swoim wskazał na historyczne znaczenie tego posiedzenia, pierwszego po 5 latach niewoli.

Po wybraniu członków Miejskiej Rady Narodowej i zaprzysiężeniu ich, głos zabrał pełnomocnik Rządu Tymczasowego na miasto Łódź ob. Mijal. Zadania, które Miejska Rada Narodowa ma do spełnienia - mówi ob. Mijal - są olbrzymie, ze względu na rolę, jaką Łódź, obecnie największe miasto w Polsce, ma do spełnienia w życiu politycznym i gospodarczym kraju.

Następnie Miejska Rada Narodowa wysłała telegramy powitalne do Marsz. Stalina, do Prez. Bieruta, do Wodza Naczelnego gen. Roli-Żymierskiego i do Premiera Rządu Tymczasowego ob. Osóbki-Morawskiego.

Sprawozdanie z działalności tymczasowego Zarządu Miasta złożył wiceprezydent ob. Jaguś. Referat o organizacji i zakresie działania Miejskiej 
Rady Narodowej miasta Łodzi wygłosił ob. Litwin, mówiąc o roli i zadaniach Łódzkiej Miejskiej Rady Narodowej. Ob. Litwin podkreślił, że posiada ona prawa wojewódzkiej Rady Narodowej i podlega bezpośrednio Krajowej Radzie Narodowej. Zakres działania Łódzkiej Miejskiej Rady Narodowej przewiduje planowanie, uchwalanie budżetu i świadczeń rzeczowych, powoływanie samorządów.

W dyskusji, która się wywiązała po referacie tow. Litwina, głos zabrali przedstawiciele 4 stronnictw demokratycznych.

Przedstawiciel PPR stwierdził, że niedociągnięcia wynikłe z pracy tymczasowego Zarządu Miejskiego były z jednej strony wynikiem biurokracji i rutyny, którą wnieśli starzy urzędnicy, z drugiej zaś strony wynikiem jawnego sabotażu lub korupcji. Aparat Zarządu Miejskiego musi być oczyszczony z elementów obcych i wrogich, dotyczy to w pierwszym rzędzie wydziału mieszkaniowego i aprowizacyjnego, jak również i wydziału zdrowia.

Prezydentem miasta Łodzi został wybrany jednogłośnie ob. Mijal. Na stanowiska wiceprezydentów obrani zostali obywatele Duniak, Galas i Ajnenkiel. Rada wybrała na posłów do K. R. N. ob. ob. Nieśmiałka (PPR), Wachowicza (PPS), Stawińskiego i Głowackiego (Zw. Zaw.), Galasa (Str. Dem.). (Prezydentem m. Łodzi został ob. Mijal, GL 1945, nr 57 [96], s. 4)

2. Na łamach „Polski Zbrojnej” kolejne relacje z frontu pióra Janiny Broniewskiej (Jeńcy, PZ 1945, nr 35, s. 3) i Tadeusza Jacka Rolickiego (Zadzierżystość, PZ 1945, nr 35, s. 2)

\section{ok. 7 marca 1945, środa}

1. Do Łodzi przyjeżdżają Jarosław Iwaszkiewicz i Stanisław Rembek. Iwaszkiewicz pozostanie tu zapewne do niedzieli, figuruje bowiem na liście uczestników poranka literackiego w Teatrze Wojska Polskiego (zob. 11 marca 1945, punkt 1.)

W Łodzi bawią obecnie przejazdem znani pisarze z Warszawy - Jarosław Iwaszkiewicz, autor Lata w Nohant (o Chopinie), oraz Stanisław Rembek, laureat nagrody pisarskiej Kasy Literackiej w Warszawie za powieść $W$ polu. (Życie kulturalne, PZ 1945, nr 36, s. 4)

\section{przed 8 marca 1945}

1. Do Łodzi sprowadzają się Stanisław Dygat i Jerzy Wyszomirski. Wyszomirski zostaje kierownikiem redakcji literackiej dziennika „Rzeczpospolita”.

Z Krakowa przybył samolotem młody pisarz Stanisław Dygat, współpracownik „Odrodzenia”. Przybyły z Milanówka znany publicysta i krytyk wileński, Jerzy Wyszomirski, osiadł w Łodzi i objął dział literacki „Rzeczypospolitej". (Życie kulturalne, PZ 1945, nr 36, s. 4) 


\section{8 marca 1945, czwartek}

1. W prasie informacje:

1.1. o trwających w Łodzi kursach pracowników propagandy

Wojewódzki Komitet Polskiej Partii Robotniczej w Łodzi zorganizował siedmiodniowy kurs propagandystów. W kursie bierze udział 110 uczestników ze wszystkich powiatów województwa łódzkiego. Program obejmuje: zagadnienia aktualnej polityki, historii ruchu robotniczego i ideologicznych założeń partii. Po zakończeniu kursu odbędzie się seminarium. Po powrocie do swych organizacji partyjnych kursanci zajmą stanowiska $\mathrm{w}$ terenowych wydziałach agitacji i propagandy. Analogiczny kurs przeznaczony dla członków organizacji łódzkiej, miejskiej, zbliża się już ku końcowi. (Z życia Partii, GL 1945, nr 57 [96], s. 4)

1.2. o pracach nad pierwszym numerem nowego pisma literackokulturalnego, redagowanego przez Zofię Nałkowską

W najbliższym czasie ukaże się w Łodzi pierwszy numer tygodnika pt. „Kuźnica”. Redakcję naczelną objęła p. Zofia Nałkowska. (Życie kulturalne, PZ 1945, nr 36, s. 4)

1.3. o staraniach zmierzających do utworzenia w Łodzi "centralnej” uczelni artystycznej

Ministerstwo Kultury i Sztuki powierzyło prof. Stanisławowi Ostoi-Chrostowskiemu, jednemu z najwybitniejszych grafików polskich, organizację Akademii Sztuk Pięknych w Łodzi, która będzie centralną wszechnicą sztuk plastycznych w Polsce. (Życie kulturalne, PZ 1945, nr 36, s. 4)

\section{4. o obchodach Międzynarodowego Dnia Kobiet}

Dziś, 8 marca, w Międzynarodowy Dzień Kobiet robotnice łódzkie pośpieszą do szpitali, by wręczyć podarunki rannym żołnierzom.

Kobiety, zrzeszone w organizacjach, postanowiły uczcić ten dzień wzmożeniem wysiłku w pracy dla dobra Ojczyzny.

W całej Polsce odbędą się uroczyste akademie. (Międzynarodowy Dzień Kobiet, PZ 1945, nr 36, s. 4)

\section{9 marca 1945, piątek}

1. W prasie:

1.1. powtórzenie informacji o planowanym druku pierwszego numeru „Kuźnicy” (Literatura i sztuka, GL 1945, nr 58 [97], s. 3)

1.2. wiersz Leopolda Lewina o potrzebie odbudowy Warszawy pt. Apel (PZ 1945, nr 37, s. 3) 
1.3. artykuł Stanisława Ryszarda Dobrowolskiego o różnicach między II RP a „Polską demokratyczną" (z aluzją do Mickiewiczowskiego Pana Tade$u s z a)$, zawierający ostre uwagi krytyczne pod adresem przeciwników władzy komunistycznej

Powracający cudem na Ojczyzny łono nie potrzebuje, aby mu tłumaczono, komu zawdzięcza wolność. Powracający najczęściej współdziała nawet w swoim wyzwoleniu - staje się współtowarzyszem broni żołnierzy Związku Radzieckiego i Wojska Polskiego.

Powracający, kiedy dostanie się wreszcie do serca Polski, przybędzie do Łodzi, Krakowa, tragicznej Warszawy, czy Lublina, wpada w istny wir nowych spraw, nieznanych mu dotychczas zagadnień, nieoczekiwanych stosunków. [...] Powracający nie dowierza, że w kraju odradza się życie polityczne, że działają tu swobodnie demokratyczne organizacje społeczne, polityczne, kulturalne. [...] Opowiadano mu niestworzone rzeczy: o NKWD, o tym, że Związek Sowiecki - to wróg cywilizacji chrześcijańskiej, że w Wojsku Polskim są komisarze bolszewiccy. Pan Goebbels działał. Pomagali panu Goebbelsowi w tym zbożnym trudzie rozmaici „polscy patrioci” spod ciemnej gwiazdy. Spółka niejawna, świadoma czy mimowiedna, funkcjonowała. Trzeba teraz naocznie przekonywać niejednego, rozbijać atmosferę podejrzeń. (S. R. Dobrowolski, Powracający cudem, PZ 1945, nr 37, s. 3)

\section{4. syntetyczny artykuł nt. odtwarzania krajowej radiofonii}

Kilka megafonów ulicznych w pojedynczych miastach - oto było wszystko, co otrzymała dyrekcja Polskiego Radia w spadku po Niemcach. Ani jedna stacja nadawcza nie uniknęła swojego losu - wysadzenia w powietrze. [...]

W toku są prace nad odbudową stacji w Łodzi, która według zobowiązania pracowników łódzkich ma być ukończona do 1-go czerwca. (W.P., Radiofonizacja Polski. [Na podstawie wywiadu z dyrektorem Polskiego Radia, ob. Billigiem], PZ 1945, nr 37, s. 4)

1.5. korespondencje wojenne Janiny Broniewskiej (Niemiecka „przeprowadzka", PZ 1945, nr 37, s. 3) i Henryka Hollanda (Wkierunku morza. Oddziaty polskie zajęty miasto Tempelburg, PZ 1945, nr 37, s. 2)

1.6. artykulik Jerzego Drewnowskiego poświęcony problemom wsi oraz ofensywie ideologicznej komunizmu (Kamieńczyk, PZ 1945, nr 37, s. 4)

\section{0 marca 1945, sobota}

1. Otwarcie świetlicy w b. fabryce Poznańskiego.

Niezwykłą i nieoczekiwaną chwilę przeżyli robotnicy zakładów państwowych dawn. I. K. Poznański w Łodzi. W sobotę dnia 10 marca r. b. odbyła się uroczystość otwarcia Świetlicy Robotniczej, co będzie kamieniem 
węgielnym przyszłej pracy oświatowej i społecznej na terenie firmy. W skromnym lokalu dawnej biblioteki i czytelni zebrała się liczna gromada robotnic i robotników wraz z Radą Załogową i Dyrekcją. Obecny był między innymi reprezentant Armii Polskiej, ob. por. Filipowicz.

Po wygłoszeniu szeregu przemówień okolicznościowych, nastąpiła część wokalno-muzyczna, podczas której pracownicy tejże firmy odegrali lub odśpiewali szereg utworów.

Przy okazji zaznaczyć należy, że Zakłady, które uruchomione zostały już w cztery dni po ucieczce niemców [sic!], w znacznej mierze są już czynne. Zakłady nasze posiadają ok. 60.000 wrzecion i 1.200 krosien. (Otwarcie świetlicy w b. zakładach Poznańskiego, GL 1945, nr 63 [102], s. 4)

2. W prasie:

2.1. informacja o powołaniu do życia Towarzystwa Robotniczych Domów Kultury, którego kierownictwo urzęduje w budynku przy ul. Piotrkowskiej 243

Z inicjatywy mas robotniczych Łodzi przy współudziale Wojewódzkiego Wydziału Kultury i Sztuki oraz Urzędu Informacji i Propagandy Województwa Łódzkiego powstaje w Łodzi Towarzystwo Robotniczych Domów Kultury w Polsce.

Zadaniem ich jest stać się ogniskiem pracy kulturalnej robotnika, zogniskować i pchnąć na właściwe tory jego wysiłki w kierunku samokształcenia, rozwijać i zaspokajać jego dążenia kulturalne i, ogarniając wszystkie dziedziny wiedzy, przybliżyć je masie robotniczej.

Szeroki program prac obmyślany wszechstronnie przy ścisłej współpracy z przedstawicielami świata literatury, muzyki, teatru i plastyki, w duchu demokratycznym, w oparciu o masy - czyni z Robotniczych Domów Kultury poważny czynnik rozwoju duchowego szerokich rzesz robotniczych. (Robotnicze Domy Kultury w Polsce, GL 1945, nr 59 [98], s. 3)

2.2. informacja „na temat tworzenia się i planów na przyszłość” Łódzkiego Domu Żołnierza

Ze względu na wielkość i znaczenie Łodzi będzie on [Łódzki Dom Żołnierza] miał specjalny zasięg i skalę działania.

Dotychczasowy CDŻ w Lublinie szedł w kierunku widowisk rewiowych, tu przewiduje się rozwój odmienny: zostanie zachowany Teatr Małych Form, z tą jednak różnicą, że punkt ciężkości zostanie położony na teatr muzyczny, tj. komedię muzyczną, wodewil i sztukę ludową; w programie będzie się uwzględniało szczególnie muzykę, tańce i śpiew ludowy.

Oddzielnie i na daleko szerszych podstawach organizuje się Teatr Kukieł, posiadający pokaźny dorobek i piękne tradycje jeszcze z 1-ej dywizji. Repertuar Teatru Kukieł obejmie aktualia polityczne, sztuki propagandowe i baśnie ludowe. [...]

[Zespoły ŁDŻ] wyjeżdżać będą do jednostek wojskowych na zapleczu i na front. 
Repertuar jest zapewniony dzięki obiecanej współpracy literatów i kompozytorów: Leca, braci Harris, Jurandota, Huszczy, Minkiewicza, Nowickiego, Pasternaka, Turzańskiego i innych.

W związku z dekoracjami padają nazwiska Mieczysława Piotrowskiego, Zaruby i Baranieckiego.

Oprócz widowisk teatralnych będą organizowane odczyty na tematy społeczne i polityczne.

Własna pracownia malarsko-rzeźbiarska [...] umożliwi urządzanie wystaw, na których specjalnie uwzględniane będą utwory o tematyce wojskowej.

Będzie czynna świetlica, dostępna też dla ludności cywilnej, wyposażona w książki, pisma codzienne i gry. [...]

W najbliższych dniach przybędzie do Łódzkiego Domu Żołnierza popularna "7-ka jazzowa" i kwartet - zespoły znane z rozgłośni lubelskiej.

Dom Żołnierza w Łodzi ma ambicje, by stać się ośrodkiem, który jednostkom wojskowym w zapleczu i na froncie dostarczy kulturalnej rozrywki i nawiąże jeszcze ściślejszy kontakt wojska z ludnością cywilną. (A. J., Łódzki Dom Żotnierza, PZ 1945, nr 38, s. 4)

2.3. apel Wojskowego Instytutu Naukowo-Wydawniczego w Łodzi o przekazywanie książek o tematyce żołnierskiej - „wszystkich uratowanych regulaminów, instrukcyj, czasopism i wszelkich wydawnictw wojskowych" - do dyspozycji Centralnej Biblioteki Wojskowej przy ul. Sienkiewicza 21 (Ratujmy polską książkę wojskowa, PZ 1945, nr 38, s. 4)

2.4. felieton Stanisława Ryszarda Dobrowolskiego, w którym epoka przedwojenna („miasto szwindlów i interesu, matactw i wyzysku, Łódź Szajblera i Grohmana") przeciwstawiona zostaje czasom obecnym

Dziś, kiedy po latach przybywam znów do tego miasta - do zwycięskiej, robotniczej Łodzi, wiem, że nie będą mnie tu nigdy już witać ani żegnać obelgą. Wiem, że to wszystko, co było ciemne i złe w tym mieście, należy do bezpowrotnej przeszłości. Witam Łódź nową - Łódź, która stanie się fundamentem budowy nowego wspaniałego życia.

[...] Może dziś uda nam się - musi się udać - wyszukać lepszy, piękniejszy wyraz dla tych ideałów, które wypieściliśmy w swoich sercach w ciągu długich lat wspólnej walki. Ideałami tymi - tamte młodzieńcze ideały: Polska prawdziwej wolności, Polska prawdziwej, rzetelnej sprawiedliwości - Polska demokratyczna.

Będziemy ją razem budować. Przystępując do tej roboty, uściśnijmy sobie ręce. (S. R. Dobrowolski, Powitanie Łodzi, GL 1945, nr 59 [98], s. 4)

\section{1 marca 1945, niedziela}

1. Pierwszy poranek literacki zorganizowany przez Związek Zawodowy Literatów Polskich. Według informacji prasowej, własne utwory mieli czytać: Jan Brzechwa, Stanisław Dygat, Pola Gojawiczyńska, Jan Huszcza, Jarosław Iwaszkiewicz, Mieczysław Jastrun, Stanisław Krzyżewski, 
Stanisław Jerzy Lec, Ryszard Matuszewski, Janusz Minkiewicz, Zofia Nałkowska, Andrzej Nowicki, Leon Pasternak, Stanisław Piętak, Seweryn Pollak, Adolf Rudnicki, Adam Ważyk, Stanisława Zakrzewska.

11 marca odbył się w sali Teatru Wojska Polskiego pierwszy poranek literacki. Przepełnione nostalgią za krajem słowo poety-emigranta zespoliło się tu z twórczością pełną bólu, męki i cierpienia tych, co okupację przeżyli w kraju. [...]

I zeszli się literaci, oddzieleni dotąd liniami frontów. Łódź - największy obecnie środek pracy i kultury - skupił i jednych, i drugich. Nowa droga, nowy szlak odkrył się teraz przed polską poezją. Określił go w słowie wstępnym Mieczysław Jastrun: na służbę odradzającego się życia, społeczności, pracy, na służbę masom.

Niech poezja i proza bierze udział „W zwycięstwie rzeczywistości nad dotychczasową fikcją, rozumu nad niedorzecznością" - wypowiada swój sąd w „kilku słowach”, z właściwą sobie przenikliwością psychologiczną, nasza sławna powieściopisarka - Nałkowska. (D. E., Pierwszy poranek literacki w Łodzi, R 1945, nr 59 [89], s. 3)

Trzeba stwierdzić, że publiczność w ogóle była aktywna i żywo reagowała. Słuchacze nie chcieli uronić ani jednego słowa i ciągle wołali "głośniej". Niestety występujący literaci nie zawsze dali się zdopingować.

Zapewne bardziej "dojdą do głosu” na jednej z przyszłych tego rodzaju imprez, które obiecała zorganizować energiczna administracja Teatru Polskiego. (A. Mikułko, Poranek Literacki w Łodzi, RZ 1945, nr 67 [207], s. 3)

\section{3 marca 1945 , wtorek}

\section{Zjazd kierowników Urzędów Informacji i Propagandy.}

W dniu wczorajszym odbył się tu Wojewódzki Zjazd sprawozdawczy powiatowych kierowników informacji i propagandy. W zjeździe wziął udział Szef Departamentu Ministerstwa Informacji i Propagandy ob. kpt. Kratko, delegaci Wojewódzkiego Urzędu Informacji i Propagandy, przedstawiciele prasy jak i dziewiętnastu przedstawicieli powiatu. (Wojew. zjazd kierowników Informacji i Propagandy, GL 1945, nr 63 [102], s. 4)

2. Otwarcie dwóch księgarń Spółdzielni Wydawniczej „Książka”, przy ul. Piotrkowskiej 55 i 105.

Księgarnie mają na składzie dzieła: klasyków marksizmu-leninizmu, beletrystykę, literaturę piękną, broszury polityczno-społeczne oraz czasopisma, materiały piśmienne i gazety. (2 księgarnie Spótdzielni Wyd. "Książka”, GL 1945, nr 64 [104], s. 4) 
3. W prasie:

3.1 informacja o ukazaniu się pierwszego tomu serii „Biblioteczka Peperowca"

Nakładem Spółdzielni Wydawniczej „Książka” ukazała się, jako pierwsza z serii ogólnej „Biblioteczki Peperowca”, broszura pióra tow. W. Gomółki [sic!] (Wiesława), sekretarza KC Polskiej Partii Robotniczej pt. PPR w walce o Niepodległość Polski i jest do nabycia w księgarni „Książki” i w kioskach gazetowych. (GL 1945, nr 62 [101], s. 4)

\section{4 marca 1945, środa}

1. W prasie:

1.1. relacja z pobytu w Łodzi ministra oświaty Stanisława Skrzeszewskiego; informacja o planach ministerstwa

W Krakowie będzie prócz Akademii oczywiście i Politechnika, oparta na bazie istniejącej tam Akademii Górniczej, a w Łodzi prócz Politechniki i czasowego Uniwersytetu warszawskiego [sic!] istnieć będzie również wyższa szkoła o typie Wolnej Wszechnicy z fakultetem medycznym, mająca prawo do stopni naukowych do habilitacji włącznie. (Zamierzenia Ministerstwa Oświaty, GL 1945, nr 63 [102], s. 4)

1.2. zapowiedź wizyty ministra kultury i sztuki Wincentego Rzymowskiego

W dniach najbliższych spodziewany jest przyjazd do Łodzi prezesa Stronnictwa Demokratycznego w Polsce Ministra Kultury i Sztuki Wincentego Rzymowskiego oraz vice-prezesa Stronnictwa, przewodniczącego Związku Dziennikarzy prof. J. Wasowskiego i vice-min. Jana Karola Wendego. (Min. Rzymowski w Łodzi, GL 1945, nr 63 [102], s. 4)

\section{5 marca 1945, czwartek}

1. Po krótkim pobycie w Krakowie Józef Zaremba i Ewa Szelburg-Zarembina przybywają do Łodzi. Zaremba obejmuje stanowisko dyrektora wydawniczego SW "Czytelnik".

I tak w pierwszych dniach marca 1945 r. zjawiliśmy się znów u Zarębskich, a nazajutrz rano w gmachu dawnego Ilustrowanego Kuriera Codziennego przyjęli mnie Zofia Dembińska i Jerzy Borejsza i zaproponowali objęcie stanowiska dyrektora wydawniczego Spółdzielni Wydawniczej "Czytelnik". Spółdzielnia została zorganizowana zaraz po wyzwoleniu w Lublinie, a po zajęciu Łodzi - przeniesiona do tego miasta. [...]

15 marca przybyliśmy do Łodzi. Po krótkim pobycie w hotelu przenieśliśmy się do ładnego dwupokojowego mieszkania przy ul. Bandurskiego, 
otrzymanego dzięki staraniom Borejszy. (J. Zaremba, Było i tak. Wspomnienia, Wrocław 1976, s. 437-439)

2. Początek rekrutacji na studia w nowo powstającym uniwersytecie.

Zapisy na wydziały: Matematyczno-Przyrodniczy, Humanistyczny, Pedagogiczny i Nauk Społecznych rozpoczynają się w czwartek dn. 15 marca r. b. w lokalu Szkoły Włókienniczej przy ul. Żeromskiego 115 w godzinach 9-13.

Zapis obowiązuje również słuchaczy zarejestrowanych poprzednio. O dniu rozpoczęcia nastąpi oddzielne zawiadomienie. (Z sekretariatu Państwowego Uniwersytetu w Łodzi, GL 1945, nr 64 [104], s. 4)

Uczelnia zajęła gmachy byłych gimnazjów przy Narutowicza 140 i al. Kościuszki 123, gmach YMCA dla studium wychowania fizycznego, oraz gmach przy ul. Żeromskiego 115 dla wydziałów politechnicznych. Przed wrześniem 1939 r. w gmachu tym była szkoła włókiennicza, zaś w czasie okupacji zorganizowano w nim szkołę inżynieryjną. [...].

Medycy mają do dyspozycji poniemieckie prosektorium miejskie, które także zachowało się w całości.

Dla wydziału rolnego Uniwersytet otrzymał wyłączony spod parcelacji majątek Żeromin, $20 \mathrm{~km}$ od Łodzi [...].

Na szeroką skalę rozwinięto akcję, mającą na celu kompletowanie księgozbiorów. Książek szuka się wszędzie. Już zebrano 10 tys. tomów literatury naukowej w różnych językach. Zabezpieczono bibliotekę Oflagu II w Woldenbergu, składającą się z 40 tys. tomów. (Jan Zagościński, Uniwersytet w Łodzi, RZ 1945, nr 63 [203], s. 3)

\section{przed 16 marca 1945}

1. Inauguracyjny program artystyczny Wisłą do Gdańska w Łódzkim Domu Żołnierza.

Z całego zespołu artystycznego Centralnego Domu Żołnierza w Lublinie przeniesiono do Łodzi tylko niewielką, pośród zupełnie prawie surowego materiału aktorskiego najbardziej wykwalifikowaną część: siódemkę jazzową i „,wesołą czwórkę” rewellersów. Wypełniają one pierwszy program Łódzkiego Domu Żołnierza.

Zwykła przerwa między pierwszą a drugą częścią spektaklu rozdzieliła go także wyraźnie na dwie różne części pod względem charakteru poszczególnych numerów.

I tak jak pierwszą część wy pełniały numery w temacie i wykonaniu dość jednolite, jeśli chodzi o charakter - ludowe i żołnierskie - montaż muzyczny Wista do Gdańska oparty na motywach regionalnych, wiersz Mrozowskiego Przywitanie Łodzi, piosenki żołnierskie w wykonaniu czwórki 
rewellersów oraz Na Berlin i Powrót, śpiewane przez Paprockiego - tak część druga nosiła charakter krańcowo różny.

Przede wszystkim od tematu części pierwszej odbiegły numery jazzowotaneczne, jakimi drugą część przeładowano. Zostały wprawdzie dobrze wykonane, bo też i bardziej odpowiadają rodzajowi instrumentów siódemki, lecz wypadły niewłaściwie na estradzie udekorowanej barwami narodowymi, gdzie wszyscy wykonawcy noszą mundury i dystynkcje wojskowe - zwłaszcza po kilku mocnych, patetycznych akcentach części poprzedniej.

Artysta-żołnierz Wojska Polskiego jest w stanie i powinien przynieść niedawno wyzwolonej publiczności łódzkiej słowo i melodię polską, które będą przemawiać do widza tak, że zbyteczna się stanie - szczera chyba - troska dyrygenta o powodzenie przedstawienia, dyktująca mu własne, nieprzewidziane produkcje choreograficzne. (baj., "Wista do Gdańska” w Domu Żotnierza, GL 1945, nr 65 [105], s. 4)

\section{6 marca 1945, piątek}

1. Paweł Hertz otrzymuje w Warszawie-Włochach „pisemny rozkaz, wystawiony [...] przez Szefa Głównego Zarządu Polityczno-Wychowawczego Wojska Polskiego pułkownika Wiktora Grosza, nakazujący [...] wyjazd z Warszawy 17 III 1945 i stawienie się w Łodzi 19 III 1945”. (P. Hertz, A. i J. Iwaszkiewiczowie, Korespondencja, t. 1, Warszawa 2015, s. 397 - przypis Agnieszki i Roberta Papieskich)

\section{przed 17 marca 1945}

1. Zebranie poświęcone powołaniu Komitetu Odbudowy Warszawy.

W Wojewódzkim Urzędzie Propagandy i Informacji odbyła się konferencja w sprawie utworzenia Komitetu Odbudowy Warszawy. Zebranie otworzył Naczelnik Wojewódzkiego Urzędu Informacji i Propagandy, przedstawiając konieczność najczynniejszego udziału całego społeczeństwa polskiego $\mathrm{w}$ akcji odbudowy stolicy.

Tymczasowa siedziba Wojewódzkiego Komitetu Odbudowy Warszawy mieści się w Urzędzie Propagandy i Informacji, ul. Traugutta 8. (Komitet odbudowy Warszawy zorganizowany, GL 1945, nr 66 [106], s. 4)

\section{Aleksander Zelwerowicz w Łodzi.}

Do Łodzi przybył znakomity artysta i reżyser scen polskich, ostatnio dyrektor Teatru Narodowego w Warszawie, Aleksander Zelwerowicz. Pozyskany on został dla Teatru Wojska Polskiego, gdzie wkrótce rozpocznie znów swą artystyczną działalność. (Aleksander Zelwerowicz w Łodzi, GL 1945 , nr 66 [106], s. 4) 


\section{nie wcześniej niż 17 marca 1945}

1. Wizyta Marii Dąbrowskiej w Łodzi. Autorka Nocy $i$ dni spotyka m.in. „wiceministra kultury i sztuki" [Wendego] oraz Mirę Zimińską; dowiaduje się od nich, że w lutym i w marcu w Lublinie przebywała Anna Kowalska.

W zeszłym tygodniu będąc w Łodzi, dowiedziałam się od przypadkowo spotkanych ludzi - wiceministra kultury i Miry Zimińskiej że w ciągu lutego i marca przebywała [Anna Kowalska z mężem] w Lublinie. (M. Dąbrowska, Dzienniki 1914-1965, pierwsze pełne wydanie w 13 tomach [bez opracowania edytorskiego] pod kierunkiem prof. dr. hab. T. Drewnowskiego, t. 5, Warszawa 2009, s. 140; zapis z 1 kwietnia 1945)

Jeśli wierzyć relacji J. K. Wendego, Dąbrowska zetknęła się z nim w mieszkaniu Nałkowskiej. Przedmiotem rozmowy był m.in. ministerialny plan wydawniczy na najbliższe miesiące.

Ustaliliśmy z ministrem, że 17 marca wybiorę się na dwa-trzy dni do Łodzi, gdzie znalazło gościnę wielu pracowników sztuki i gdzie - z powodu totalnego zniszczenia lewobrzeżnej Warszawy - mieściły się również niektóre działy centralnej administracji państwowej i gospodarczej. [...] Tam też Ministerstwo Kultury zaleciło czasowo skoncentrować niektóre agendy odradzającego się życia kulturalnego.

W Łodzi oprócz ogólnego „przyjrzenia się” państwowym instytucjom i społecznym ośrodkom kultury miałem za zadanie przekonsultowanie wydania [...] zestawu stu - stu pięćdziesięciu tytułów „żelaznego funduszu" najcenniejszych utworów literatury pięknej - polskiej i obcej. Odbyłem rozmowy z pisarzami, polonistami, krytykami.

Umówiłem się też między innymi z Zofią Nałkowską, która zaprosiła mnie na herbatę [...]. Poza sprawą „żelaznego funduszu” miałem z nią omówić, jako posłem do KRN, problemy związane z powstałym z inicjatywy prezydenta Bieruta Komitetem Oświęcimskim. Trudu przewodniczenia, na prośbę prezydenta, podjęła się właśnie pani Zofia.

U Nałkowskiej zastałem Marię Dąbrowską. Wedle relacji pani Zofii „wpadła na chwilę"; mieszkała stosunkowo niedaleko Łodzi w łowickiem [...]. Dąbrowskiej przed wojną nie znałem. [...]

Dąbrowska mówiła mało. Przysłuchiwała się rozmowie, obserwowała, co mnie wyraźnie deprymowało. Myślę, że nawet pani Zofia była skrępowana milczeniem Dąbrowskiej. [...]

Poruszyłem sprawę, dla której głównie przyszedłem - szybkiego wznowienia dzieł literatury pięknej. [...]

Nastąpiła wymiana zdań co do trafności zestawu. Między dwiema znakomitymi pisarkami zaznaczyły się różnice dotyczące jedynie ilości pozycji literatury obcej: Nałkowska trwała w niezmiennej miłości do pisarzy francuskich, do tytułów na ogół znanych, „murowanych”, Dąbrowska natomiast obok dzieł, powiedzmy, klasycznych, prozy i dramatu angielskiego i skandynawskiego - dopominała się o zwiększenie pozycji 
literatury amerykańskiej. (J. K. Wende, Ta ziemia od innych droższa..., Warszawa 1981, s. 282-285)

\section{8 marca 1945, niedziela}

1. Na walnym zebraniu ZZLP wybrany zostaje nowy zarząd oddziału. Do 7 października obowiązki prezesa pełnić będzie Jan Brzechwa.

18 marca odbyło się w Domu Literata walne zebranie Oddziału Łódzkiego Związku Zaw. Literatów Polskich. Sprawozdanie z działalności ustępującego zarządu złożył poeta Jan Brzechwa. Po sprawozdaniu wybrano nowy Zarząd, w skład którego weszli: Pola Gojawiczyńska, Ewa Szelburg-Zarembina, Adolf Rudnicki, Jan Brzechwa i Janusz Minkiewicz. (Nowy Zarząd Zw. Literatów, GL 1945, nr 68 [108], s. 4)

2. Ukazuje się pierwszy łódzki numer „Wsi”, „tygodnika społeczno-kulturalnego" anonsowanego jako „organ Związku Samopomocy Chłopskiej”. Redaktor naczelny - Jan Aleksander Król, redakcja - ul. Piotrkowska 96, wydawca - SW „Czytelnik”. W piśmie m.in.:

2.1. propagandowy artykuł o reformie rolnej

Na obszarnictwo, jako na panującą klasę społeczną, został w nowej Polsce wydany wyrok zagłady. Taką siłę skutku ma ogłoszona i już w części wypełniona Reforma Rolna. Bo kto myśli, że obszarnik przez Reformę Rolną ziemię TYLKO utraci, ten się myli, tak samo, jakby mówił, że chłop na Reformie zyska TYLKO ziemię. [...]

Dziś w majestacie odradzającego się narodu, w majestacie demokratycznego państwa polskiego testament historii chłopów został wreszcie otwarty. Późno - to prawda. Ale nic w nim nie zwietrzało. W zmienionych warunkach te same bolą rany, idzie o zniesienie tej samej w gruncie krzywdy społecznej. (J. A. Król, Obszarnik bez ziemi, W 1945, nr 2 [9], s. 1)

2.2. wiersze Władysława Milczarka, Jana Raka, Zdzisława Skwarczyńskiego, Stanisława Cielocha i Stanisława Piętaka;

2.3. fragment wspomnień Stefana Lichańskiego pt. Oświęcim

2.4. Samopomoc. Kartki z dziennika podróży Jerzego Drewnowskiego.

3. Oficjalna inauguracja działalności Robotniczego Domu Kultury. Słowo na temat Komuny Paryskiej wygłosiła Regina Kobryńska-Kapłan (właśc. Zofia Cytryn) z Centralnej Szkoły PPR. W części artystycznej wystąpili m.in. Zdzisław Górzyński (dyrygował orkiestrą symfoniczną, wykonującą fragmenty oper Moniuszki), Krystyna Jastrzębska (fortepian), Wanda Wiłkomirka (skrzypce), Mira Zimińska (melorecytacja wierszy Tuwima i Minkiewicza), Janina Rudnicka (taniec)

Dziś w niedzielę dnia 18 marca 1945 r. o g. 11 rano odbędzie się uroczyste otwarcie Robotniczego Domu Kultury przy ul. Piotrkowskiej 243. 
Na porządek dzienny złożą się: a) przemówienie i powitanie, b) w części artystycznej wystąpią: orkiestra symfoniczna pod dyrekcją Zdzisława Górzyńskiego, poza tym artystki i artyści teatru łódzkiego.

O g. 15 - otwarcie prac sekcji społecznej. Poza przemówieniami i produkcjami artystycznymi, recytacja utworów pisarzy łódzkich i odczyt ob. Słotwińskiego pt. O demokratyzację życia w Polsce. Wstęp wolny. (Otwarcie Robotniczych Domów Kultury, GL 1945, nr 67 [107], s. 4)

Dnia 18 marca odbyło się uroczyste otwarcie Robotniczego Domu Kultury w Łodzi.

W krótkim zagajeniu ob. Sokołowski skreślił zadania i rolę Robotniczego Domu Kultury i ogólnego rozwoju robotniczej kultury, której ideałem jest pomoc w dążeniu do wolności i braterstwa. W Domach Kultury robotnicy zetkną się z artystami i twórcami intelektualnych wartości i tym samym staną się one podwaliną kultury całego narodu.

Robotnicze Domy Kultury to pomniki chwili, które podarowała historia. Dzień otwarcia zbiegł się z 74-tą rocznicą Komuny Paryskiej. W związku z tym ob. Regina Kobryńska skreśliła obrazowo dzieje paryskiej proletariackiej rewolucji, jej tragiczny upadek, osiągnięcia i błędy.

Pierwszy Robotniczy Dom Kultury w Łodzi będzie podwaliną, która rozpocznie pokrywanie siecią takich domów całego państwa polskiego. (Otwarcie Robotniczego Domu Kultury, RZ 1945, nr 75 [215], s. 4)

4. W Teatrze Wojska Polskiego „zgromadzenie publiczne” zorganizowane przez koncesjonowane Stronnictwo Demokratyczne.

W niedzielę, tj. 18 marca 1945 r. o g. 10 rano odbędzie się w sali Teatru Wojska Polskiego przy ul. Cegielnianej wielkie zgromadzenie publiczne, zwołane przez Stronnictwo Demokratyczne w Łodzi. Referat polityczny wygłosi Minister Kultury i Sztuki ob. Wincenty Rzymowski. Poza tym przemawiać będzie Wiceminister Kultury i Sztuki Jan Karol Wende, wiceprezes Stronnictwa Demokratycznego, Józef Wasowski i inni. Wstęp bezpłatny. (Zebranie Str. Demokratycznego, GL 1945, nr 65 [105], s. 4)

5. Zebranie organizacyjne członków przedwojennego ZAiKS-u („autorów scenicznych, przekładców itd.”), w sali „ekspozytury Ministerstwa Kultury i Sztuki przy ul. Kościuszki 70 (dawny Kościuszki 136)” (Zebranie członków b. Zaiksu, GL 1945, nr 67 [107], s. 4)

6. W „Głosie Ludu” (1945, nr 67 [107], s. 3) blok ideologicznych tekstów poświęconych Komunie Paryskiej, wśród nich:

6.1. artykuł Romana Werfla Rocznica Komuny Paryskiej, pełen aluzji dot. bieżącej sytuacji politycznej, przedstawiający francuski konflikt społeczny sprzed siedmiu dekad jako prefigurację sytuacji polskiej w przededniu zakończenia II wojny światowej

Na te reakcyjne przedmieścia [Paryża] spoglądał z nienawiścią reakcyjny rząd kapitalistów i zaprzedańców. Z nimi chciał się rozprawić sztab 
generałów, którzy nie potrafili zwyciężać zewnętrznego wroga na polu bitwy. Ale aby rozprawić się z robotniczymi przedmieściami, trzeba było przede wszystkim odebrać robotnikom broń. [...]

Na próżno dowódca wojsk Komuny - Polak, jeden z organizatorów naszego Powstania Styczniowego, Jarosław Dąbrowski - wytężał wszystkie siły, aby zahamować posuwanie się naprzód wroga, na próżno na barykady Paryża wylegli starzy i młodzi, kobiety i starcy. [...] Reakcja zatriumfowała raz jeszcze.

Ale jej triumf nie był wieczny.

Odrodził się skrwawiony, pozbawiony tysięcy swych bojowników ruch robotniczy Francji. Odrodził się - wierny czerwonemu sztandarowi Komuny, bardziej dalekowzroczny od wielu jej kierowników.

Wyciągnął naukę z doświadczeń Komuny międzynarodowy ruch robotniczy. Kiedy w 1917 r. podniosły się do walki o rząd robotników i chłopów masy ludowe Rosji, ich wódz, Włodzimierz Lenin, rzucił hasło: "Chcemy władzy Rad, chcemy takiego państwa, jakim była Komuna Paryska". Kiedy dziś na polach bitew, pod wodzą marsz. Stalina Armia Czerwona zwycięża armię niemieckiego imperializmu, który kiedyś dopomógł Thiersowi zdławić we krwi Komunę Paryską, można śmiało powiedzieć: to spadkobiercy Komuny gromią spadkobierców jej katów.

6.2. wiersz Seweryna Pollaka Pottier, zakończony następującą strofą: „Dziś wiemy, że to bój ostatni, / że wreszcie trud się skończy krwawy, / a pieśń nas w związek łączy bratni / przez Paryż, Madryt - do Warszawy" 6.3. wiersz Nikołaja Asiejewa 18 marca w przekładzie S. Pollaka.

\section{9 marca 1945, poniedziałek}

1. Paweł Hertz wysyła do Jarosława Iwaszkiewicza telegram: „Jestem Łódź Savoy serdecznie pozdrawiam Ciebie panią Hanię Paweł”. (P. Hertz, A. i J. Iwaszkiewiczowie, Korespondencja, t. 1, Warszawa 2015, s. 100)

\section{0 marca 1945, wtorek}

1. W prasie:

1.1. informacja o przeniesieniu do Łodzi Zarządu Głównego ZMW „Wici”

Do robotniczejŁodzi przybył po dłuższym pobycie w Warszawie pełny skład Zarządu Głównego Związku Młodzieży Wiejskiej R. P. „Wici”, który z Łodzi kierować będzie pracami młodzieży chłopskiej. Do Łodzi przeniesiona została również redakcja organu związkowego. Ze względu na doniosłość uchwał, jakie ma podjąć Zarząd Główny, na swym pierwszym posiedzeniu w Łodzi spodziewany jest przyjazd delegatury Zarządu Głównego na Warszawę. (Zarząd Główny „Wici” przenióst się do Łodzi, GL 1945, nr 69 [109], s. 4) 
1.2. wezwanie do składania książek rosyjskich w miejskiej bibliotece

Wydział Oświaty i Kultury Zarządu Miejskiego w Łodzi zwraca się z gorącym apelem do wszystkich mieszkańców m. Łodzi, posiadających książki rosyjskie, ażeby te z nich, które nadają się do czytania dla rannych żołnierzy rosyjskich, składali w Miejskiej Bibliotece Publicznej (Andrzeja 14) w godzinach urzędowych.

Ulżenie cierpieniom żołnierza, który przyczynił się do wyzwolenia nas z jarzma zaborcy, uprzyjemnienie mu pobytu w szpitalu - to obowiązek serca i sumienia polskiego. (Ksiażki dla rannych żotnierzy rosyjskich, RZ 1945 , nr 76 [216], s. 4)

\section{2 marca 1945, czwartek}

1. Pierwsza premiera Teatru Wojska Polskiego w Łodzi - Wesele Stanisława Wyspiańskiego (reżyseria - Jacek Woszczerowicz; dekoracje - Stanisław Teisseyre; muzyka - Aleksander Barchacz; wystąpili m.in. Władysław Krasnowiecki, Jan Świderski, Maria Chodecka, Jan Kreczmar, Bronisława Gersonówna, Zofia Mrozowska, Elżbieta Barszczewska, Kazimierz Wichniarz, Seweryna Broniszówna, Andrzej Łapicki, Ryszarda Hanin, Aleksander Zelwerowicz, Halina Kossobudzka, Jacek Woszczerowicz, Marian Nowicki)

Dyrekcji Teatru Wojska Polskiego udało się pozyskać dla stałej współpracy znakomitego artystę i reżysera, ostatnio dyrektora Teatru Narodowego w Warszawie - Aleksandra Zelwerowicza, którego nazwisko związane z najpiękniejszymi kartami współczesnego teatru w Polsce, wiąże się również bardzo ściśle z Łodzią. Tu Zelwerowicz rozpoczynał swą karierę teatralną i tu w ciągu swej długoletniej działalności wiązał się wielokrotnie swą stałą współpracą artystyczną i społeczną. [...]

Zaangażowany obecnie przez Teatr Wojska Polskiego Zelwerowicz, którego nazwisko tak ściśle jest związane z Weselem i jego triumfem na scenie łódzkiej, rozpoczyna swą działalność w tymże Weselu, sam sobie wybierając epizodyczną rolę księdza, podkreślając przez to, że w sztuce takiej jak Wesele każda pozycja aktorska, czy w głównej, czy w epizodycznej roli, ma równie wielką artystyczną wagę.

Równocześnie Zelwerowicz będzie organizatorem i dyrektorem Państwowego Instytutu Sztuki Teatralnej w Łodzi. (Aleksander Zelwerowicz $w$ Łodzi, RZ 1945, nr 75 [215], s. 4)

2. Inauguracja zajęć uniwersyteckich.

Sekretariat Państwowego Uniwersytetu w Łodzi „Wolna Wszechnica Polska” podaje do wiadomości, że wykłady na Wydziale Matematyczno-Przyrodniczym, Humanistycznym i Pedagogicznym rozpoczną się w czwartek dn. 22 b. m. 
Wykłady odbywać się będą w lokalu Państwowej Szkoły Włókienniczej - Żeromskiego 115.

O terminie rozpoczęcia wykładów na Wydziale Nauk Społecznych nastąpi oddzielna wzmianka.

Zapisy na Wydziały trwają w dalszym ciągu. Biura Sekretariatu czynne są codziennie w godz. 9-12 i 15-17 w lokalu Państwowej Szkoły Włókienniczej - Żeromskiego 115. (Otwarcie Uniwersytetu w Łodzi, GL 1945, nr 70 [110], s. 4)

3. $\mathrm{W}$ prasie:

31. na łamach „Rzeczpospolitej” (1945, nr 77 [217], s. 2-3) tekst Mariana Podkowińskiego Rozmowy o Polsce. Pisarze polscy wobec nowej rzeczywistości, prezentujący refleksje J. Iwaszkiewicza, M. Jastruna, P. Gojawiczyńskiej i Z. Nałkowskiej.

\section{3 marca 1945, piątek}

1. Przesłuchania wstępne kandydatów do Studia Dramatycznego łódzkiego Teatru Miejskiego.

Dyrekcja Teatru Miejskiego w Łodzi komunikuje, iż w piątek 23 marca o godz. 10-ej rano w lokalu Studia Dramatycznego przy ul. Gdańskiej 32 (były pałac Poznańskich) odbędzie się egzamin dla kandydatów. (Egzaminy w Studio Dramatycznym, RZ 1945, nr 76 [216], s. 4)

2. W prasie:

2.1. tekst Leona Kruczkowskiego, do niedawna więźnia niemieckiego obozu jenieckiego

Gdy dzisiaj odurzony kroczę przez pierwsze dni odzyskanej wolności, myśl o przeklętych pięciu latach za drutem kolczastym odżywa strzępami, jak odkręcany bezładnie, kiepski, ponury film.

Film „made in Germany”, rozdarty, rozszarpany bagnetem ze stali wytopionej w hutach radzieckich. W krzepkich rękach polskiego żołnierza widziałem ten bagnet w szary, lutowy poranek - był to wyzwalający błysk. [...]

Numer 665, II B. już nie istnieje. Wyszedł w szerokie gościńce człowiek wolny i ze wzruszeniem salutuje wolnych braci - wybawców znad Wisły, znad Wołgi, znad cichego Donu.

A jutro, pisarzu polski, do pracy! Odpłacić dług odzyskanego oddechu. Nigdy w całości, bo zbyt ogromny dług przywróconego życia. (L. Kruczkowski, Nazajutrz po powrocie, GL 1945, nr 72 [112], s. 3)

2.2. zapiski reportażowe Listy z Oświęcimia Stanisława Ryszarda Dobrowolskiego (GL 1945, nr 72 [112], s. 3)

2.3. informacja o planowanym uruchomieniu połączeń lotniczych z Łodzią 
Polska komunikacja lotnicza wchodzi obecnie na właściwe tory. Z dniem 1 kwietnia uruchomione zostaną linie lotnicze na szlaku: WarszawaŁódź-Kraków-Lublin-Warszawa, zaś w połowie kwietnia: Łódź-Poznań-Wrocław-Katowice-Łódź. Z dniem 1 maja przewidziana jest trasa: Warszawa-Hallenstein-Gdańsk-Bydgoszcz-Warszawa i Łódź-WarszawaBiałystok-Warszawa. [...] Obecnie Wydział Lotnictwa Cywilnego formuje i przydziela dla sprawnego funkcjonowania linii powietrznej radiostacje, które obsługiwać będą lotniska I, II i III klasy. Do I klasy należy Warszawa i Łódź, do II-ej Kraków, Białystok, Poznań, Rzeszów, Wrocław i Gdańsk. Do III-ej: Lublin, Kielce, Bydgoszcz, Katowice i Hallenstein. (Maria Wardasówna, Rozwój polskiej komunikacji lotniczej, RZ 1945, nr 78 [218], s. 3)

\section{4. sprawozdanie z pierwszych tygodni działania poczty łódzkiej}

W porównaniu do stosunków przedwojennych nastąpiły pewne zmiany organizacyjne. Mianowicie zorganizowano w Łodzi Dyrekcję Okręgową Poczt i Telegrafu - urząd, którego tu przed wojną nie było. Dyrekcji podlega ok. 270 urzędów i agencji na obszarze wojewódzkim. Łódź, Piotrków i Łowicz posiadają rejonowe urzędy telegraficzne.

Na terenie Łodzi działa 17 urzędów pocztowych i jeden rejonowy urząd telegraficzny. Innowację stanowi stworzenie Urzędu Telefonów Miejskich [...]. Z inicjatywy dyrektora ob. Zielińskiego powstała w Łodzi niezmiernie ważna placówka: Państwowe Zakłady Graficzne wypuszczające miliony znaczków na całą Polskę.

Staraniom dyrektora i pracowników zawdzięczać należy powstanie Pocztowego Urzędu Przewozowego, który własnymi siłami (w braku benzyny - generatory na koks i drzewo) obsługuje niektóre linie. W zakres kompetencji poczty wchodzą obroty listowe (zwiększają się one z dniem każdym), obroty pieniężne (dość słabe na razie), ruch telegraficzny oraz telefony. Zaznaczyć należy, że prowadzić już można rozmowy telefoniczne zamiejscowe - między wszystkimi miastami powiatowymi. Łódź posiada ok. 1500 aparatów telefonicznych, których ilość rośnie z dniem każdym. [...]

W wyniku konferencji pocztowo-komunikacyjnej Łódź otrzyma kilka wagonów pocztowych, co usprawni działanie poczty. Obecnie oprócz ambulansów kolejowych pocztę przewożą własne samochody, kursujące co drugi dzień na trasie Warszawa-Łódź. Prócz tego 3 razy dziennie samochody dostarczają pocztę na lotnisko. Pocztowe auta przewożą dzienniki dla rządu Rzeczypospolitej do Warszawy. (m.h.ż., Poczta łódzka pracuje, RZ 1945, nr 78 [218], s. 4)

\section{4 marca 1945, sobota}

1. "Zgromadzenie publiczne" w hali sportowej w Parku Poniatowskiego z przemówieniem ks. Oraczewskiego nt. „ku czemu idzie Polska”; dochód przeznaczony na odbudowę Warszawy.(Zgromadzenie publiczne, GL 1945 , nr 73 [113], s. 4) 
2. W prasie:

2.1. na pierwszej stronie "Głosu Ludu” programowy artykuł Odrodzenie kultury polskiej

Rodzi się na odrodzonej ziemi nowy typ oświaty - oświaty dla dorosłych, masowej, szerokiej akcji oświatowej, prowadzonej przez państwo i czynniki społeczne. Dopiero kilka dni temu otwarty został w Łodzi wielki Dom Kultury Robotniczej. W każdej z naszych fabryk, w setkach wsi, powstają świetlice, rosną nowe organizacje kulturalne. Cały nasz naród, wszystkie jego warstwy, chciwie wdychają ożywczy prąd kultury polskiej, którą niemiecki wróg chciał wytępić na zawsze.

W Krakowie i w Łodzi państwo oddaje do dyspozycji Związku Literatów obszerne nowoczesne domy, aby literat polski, szczuty i prześladowany przez tyle lat, mógł swobodnie zasiąść do twórczej pracy. Stają u literackiego warsztatu dziesiątki pisarzy, którym tak długo kneblował usta hitlerowski zbir.

[...] kultura polska staje dziś przed okresem nowego, wielkiego rozkwitu. Masy ludowe, tak długo pasierb własnej Ojczyzny, przejmują dziś kulturę polską. (Odrodzenie kultury polskiej, GL 1945, nr 73 [113], s. 1)

2.2. motywowane ideologicznie przypomnienie postaci Michała Drzymały

Redakcję naszą odwiedził Jan Drzymała - wnuk sławnego chłopa-patrioty, Michała Drzymały - i opowiedział nam historię swego wielkiego dziada. [...]

Jest w postaci Drzymały wspaniałość chłopska i wspaniałość polska. Jest upór i przywiązanie do ziemi, jest nienawiść do ugody z wrogiem, jest umiłowanie ojczyzny ponad wszelkie korzyści materialne.

I dlatego, kiedy Drzymała umarł w r. 1937, cała Polska żegnała go z żalem. [...]

Po śmierci Wielkiego Chłopa, który był symbolem hartu ducha polskiego w walce z pruskim zaborcą o polską ziemię, odznaczono go orderem „Polonia Restituta”. To piękne odznaczenie miało zapewne wyrównać krzywdę, jaką wyrządzono mu za życia. Tą krzywdą był fakt, że dopiero w dwadzieścia lat po wskrzeszeniu ojczyzny, o którą walczył ten bojownik o wspaniałej postawie - uznano za właściwe podkreślenie jego zasług. Bowiem cicho było o nim w Polsce dopóki żył. [...]

Społeczeństwo i władze ówczesnej Polski zapomniały o sprawie „Wozu Drzymały”. Wyciągnął ją dopiero na światło dzienne znany literat, Józef Weyssenhoff [...]. (H. Bułharowska, Ten, co na wozie wjechat do historii, RZ 1945, nr 79 [219], s. 3)

2.4. recenzja łódzkiej inscenizacji Wesela S. Wyspiańskiego (jw. [Jerzy Wyszomirski], "Wesele” w Teatrze Wojska Polskiego, RZ 1945, nr 79 [219], s. 3) 


\section{5 marca 1945, niedziela}

1. Poranek literacki w Domu Śpiewaków.

Polski czerwony Krzyż zawiadamia, że w niedzielę dnia 25 bm. odbędzie się Poranek Literacki w Domu Śpiewaków, przy ul. 11 Listopada 21.

Udział w poranku wezmą: Jan Brzechwa, Jan Ruszcza [właśc. Huszcza], Stanisław Krzyżewski, Janusz Minkiewicz, Leon Pasternak, Adolf Rudnicki, Stanisław Dygat, Jarosław Iwaszkiewicz, Stanisław Jerzy Lec, Zofia Nałkowska, Stanisław Piętak, Adam Ważyk, Pola Gojawiczyńska, Mieczysław Jastrun, Ryszard Matuszewski, Andrzej Nowicki, Seweryn Pollak, Stanisława Zakrzewska, Ewa Szelburg-Zarembina.

Całkowity dochód na rzecz Polskiego Czerwonego Krzyża w Łodzi. Początek poranku o godz. 10.45. Z chwilą rozpoczęcia recytacji drzwi na salę zostaną zamknięte. (Poranek literacki, GL 1945, nr 71 [111], s. 4)

2. Ostatnie wystawienie programu artystycznego Nasza jest Łódź w Sali Śpiewaków (ul. 11 Listopada 21)

W sobotę 24 i niedzielę 25 po raz ostatni [...] odbędzie się widowisko literacko-artystyczne w 2-ch częściach, 18 obrazach pod nazwą Nasza jest Łódź, z udziałem znanych artystów scen łódzkich.

W programie recytacje nastrojowe, inscenizacje, skecze, piosenki aktualno-propagandowe oraz tańce regionalne. („Nasza jest Łódź”, RZ 1945 , nr 79 [219], s. 4)

3. "Koncert retrospektywny” Teatru Wojska Polskiego pt. Od Oki do Wisty.

Na program tego koncertu retrospekcyjnego złożą się marsze i pieśni, tańce i kompozycje sceniczne, które towarzyszyły żołnierzowi polskiemu w marszu bojowym znad Oki do Wisły, oraz związane z tym jedynym niepowtarzalnym okresem wiersze poetów 1-ej Armii - Leona Pasternaka, Jerzego Putramenta, Lucjana Szenwalda, Adama Ważyka. O działalności Teatru Wojskowego od estrady 1-ej Dywizji aż do wielkiej sceny dramatycznej Teatru Wojska Polskiego będzie mówił Władysław Krasnowiecki. Słowo wstępne wygłosi Adam Ważyk. („Od Oki do Wisty”, GL 1945, nr 74 [114], s. 4)

W niedzielę, dnia 25-go odbędzie się w Teatrze Wojska Polskiego Wielki Poranek Artystyczny poświęcony twórczości Pierwszej Armii na terenie ZSRR - od chwili formowania 1-szych oddziałów polskich w Rosji nad Oką aż do osiągnięcia przez nich Wisły. (Od Oki do Wisty, RZ 1945, nr 78 [218], s. 4)

Publiczność przyjęła aktorów z olbrzymią życzliwością, wzruszały ją głęboko słowa płynące ze sceny pełne nostalgii i tęsknoty, jak 
montaż Wisła z przepiękną inscenizacją wiersza A. Ważyka Sukmana, bawił ją humor wyrażony w wodewilu żołnierskim pt. Zabawa w saperów a zwłaszcza groteska Do widzenia na Unter der [sic!] Linden pióra Leona Pasternaka.

Szkoda, że było to tylko jedno przedstawienie, bo warto, by szerokie rzesze naszego społeczeństwa mogły się zaznajomić bliżej z tego rodzaju teatrem. (I. Zar., Teatr zrodzony z tęsknoty, RZ 1945, nr 83 [223], s. 4)

\section{Otwarcie świetlicy PPR w dzielnicy Górna Prawa.}

W ubiegłą niedzielę [...] odbyło się w lokalu przy ul. Bednarskiej 42 uroczyste otwarcie Świetlicy i biblioteki. Słowo wstępne wygłosił tow. Dyraga, sekretarz II dzielnicy. Na program składały się występy sekcji muzycznej, recytacje poezji proletariackiej i referaty o książce i świetlicy. (Otwarcie świetlicy PPR Dzielnica Górna Prawa, GL 1945, nr 76 [116], s. 4)

5. W prasie:

5.1. felieton Jerzego Wyszomirskiego o podobieństwach i różnicach między epoką przedwojenną a teraźniejszością (Przebierańcy, RZ 1945, nr 80 [220], s. 2-3)

5.2. debiut poetycki Pawła Hertza w powojennej prasie łódzkiej - wiersz *** [Jaka ty będziesz? Czy dwukolorowa...] (RZ 1945, nr 80 [220], s. 3)

5.3. list Janusza Minkiewicza do redakcji „Rzeczpospolitej” ws. udziału $\mathrm{w}$,poranku literackim”

Z notatki w "Głosie Ludu" i zawiadomień rozplakatowanych na mieście dowiedziałem się o moim rzekomym udziale w poranku literackim zapowiedzianym na 25 bm. Pragnę tą drogą ostrzec publiczność, iż jest wprowadzoną w błąd, gdyż w poranku tym udziału nie wezmę, jako że nikt się do mnie w tej sprawie nie zwracał. (J. Minkiewicz, List do Redakcji, RZ 1945, nr 80 [220], s. 4)

\section{5-26 marca 1945, niedziela-poniedziałek}

1. 5. Zjazd prokomunistycznego Stronnictwa Ludowego w Łodzi.

W dniu 25.3. br. w sali Wojewódzkiej Rady Narodowej w Łodzi rozpoczęło się rozszerzone posiedzenie Zarządu Głównego z okresu konspiracji i Rady Naczelnej Stronnictwa Ludowego z udziałem delegatów nowo wyzwolonych województw: krakowskiego, śląskiego, warszawskiego, kieleckiego, łódzkiego, poznańskiego i pomorskiego. Na posiedzenie przybyli min. Rolnictwa i Reform Rolnych ob. Bertold, min. Sprawiedliwości ob. Zalewski, min. Administracji Publicznej ob. Maślanka, podsekretarz Stanu w Min. Rolnictwa i Reform Rolnych ob. Szyszko, wojewoda łódzki ob. Kocioł, prezydent m. Łodzi ob. Mijal, płk. Loga-Sowiński, posłowie do KRN, ob. Jedrowicz, delegat Związku Patriotów Polskich w Moskwie 
ob. Musiał. Obradom przewodniczył znany działacz i pisarz ludowy ob. [Władysław] Kowalski.

Posiedzenie otworzył wicepremier Janusz, który powiedział: „Zagajam w Ojczyźnie naszej, w Polsce, o której marzyli nasi wieszcze, do której tęsknili nasi praojcowie. [...] Stronnictwo Ludowe bierze udział w rządzie Demokratycznej Polski, mając w niej silną reprezentację. [...] Przy pomocy bratniej organizacji robotniczej zlikwidowaliśmy klasę magnatów i obszarników, którzy nas gnębili przez całe wieki. [...]

Uchwalono wysłanie depesz do Prezydenta Krajowej Rady Narodowej ob. Bieruta, do Premiera Tymczasowego Rządu R.P. ob. Osóbki-Morawskiego, do Naczelnego Dowódcy Wojsk Polskich gen. broni Roli-Żymierskiego, oraz do Wielkiego Marszałka ZSRR Józefa Stalina. [...]

W drugim swym przemówieniu wicepremier Janusz odkrył przed zebranymi kulisy perfidnej działalności politycznej tzw. „rządu londyńskiego" i zapewnił zebranych o zdecydowanej woli czynników rządowych do bezwzględnej walki z reakcją i do solidarnego działania w ramach sojusz chłopsko-robotniczego. (Zjazd Stronnictwa Ludowego, GL 1945, nr 75 [115], s. 4)

Zjazd [...] wyraża gorące podziękowanie czynnikom rządowym za szybkie i zdecydowane przeprowadzenie reformy rolnej, [...] torującej chłopu polskiemu drogę do dobrobytu i kultury [...] potępia w całej rozciągłości zgubną dla narodu politykę emigracyjnej kliki tzw. „rządu londyńskiego" [...] wyraża przekonanie, że działalność tej grupy reakcyjnej nie ma nic wspólnego z interesem znacznej większości demokratycznego społeczeństwa polskiego, które z oburzeniem i wstydem dowiaduje się o jej poczynaniach [...] wzywa legalny Rząd Polski w kraju do usilnych poczynań celem ostatecznej likwidacji przedstawicielstwa reakcji polskiej wśród sprzymierzonych narodów demokratycznych. [...] Zjazd Rady Naczelnej Stronnictwa Ludowego stwierdza, że obecny Tymczasowy Rząd R. P. chłopów i robotników realizuje wszystkie postulaty Stronnictwa Ludowego [...] wyraża życzenie, aby Rząd ten utrzymał nadal dotychczasowy kierunek działalności i udziela mu pełnego poparcia. (Uchwały R.N. Stronnictwa Ludowego, GL 1945, nr 79 [119], s. 3)

\section{nie później niż 27 marca 1945, wtorek ${ }^{1}$}

1. Rozpoczynają się zapisy do Państwowego Instytutu Sztuki Teatralnej w Łodzi.

(Wydziały: aktorski, reżyserski i filmowy). Informacje i zapisy w tymczasowej Kancelarii PIST-u, ul. Cegielniana 32, I p., drzwi na lewo, codziennie

\footnotetext{
${ }^{1} 27$ marca 1945 r. jako datę wznowienia działalności PIST wskazuje Marta Fik (Kultura
} polska po Jatcie. Kronika lat 1944-1981, t. I, Warszawa 1991, s. 34). 
(prócz niedziel i świąt) od godz. 9-15. A. Zelwerowicz - dyrektor. (Państwowy Instytut Sztuki Teatralnej, GL 1945, nr 76 [116], s. 4)

\section{7 marca 1945, wtorek}

1.Wśródkrótkichinformacjiumieszczonychna4.stronie „Rzeczpospolitej” notka następującej treści: „DO ŁODZI przybyła znakomita powieściopisarka p. Maria Dąbrowska". (Z kroniki kulturalno-literackiej, RZ 1945, nr 82 [222], s. 4)

\section{8 marca 1945, środa}

1. W "Głosie Ludu" artykuł Seweryna Pollaka poświęcony postaci Maksyma Gorkiego - z okazji 77. rocznicy urodzin "pisarza proletariackiego". (Maksym Gorkij, GL 1945, nr 76, s. 3)

\section{9 marca 1945, Wielki Czwartek}

1. W prasie:

1.1. informacja o działalności Teatru Wojska Polskiego w ostatnich dniach Wielkiego Tygodnia i podczas świąt Wielkiej Nocy

Teatr Wojska Polskiego gra w tygodniu przedświątecznym do czwartku włącznie Wesele. W Wielki Piątek, Sobotę oraz Niedzielę świąteczną przedstawienie zawieszone. W poniedziałek świąteczny o godzinie $11 \mathrm{z}$ rana poranek Od Oki do Wisty, po południu Wesele, które od wtorku poświątecznego grane będzie codziennie. (Teatr Wojska Polskiego, RZ 1945, nr 89 [229], s. 4)

1.2. w tej samej nocie informacja o dołączeniu do zespołu TWP trojga nowych aktorów oraz zapowiedź kolejnych spektakli - Dożywocia Fredry i Fantazego Słowackiego

W próbach pod kierunkiem reżyserskim Jana Kreczmara komedia Aleksandra Fredry Dożywocie.

Do Teatru Wojska Polskiego przybyli aktorzy: Elżbieta Barszczewska i Marian Wyrzykowski, którzy w rolach Maryny i Poety wystąpią w Weselu, Janina Romanówna, która wystąpi w jednej z najbliższych premier Teatru Wojska Polskiego w dramacie Juliusza Słowackiego Fantazy w roli hrabiny Idalii. Fantazego reżyserować będzie Juliusz Osterwa. (Teatr Wojska Polskiego, RZ 1945, nr 89 [229], s. 4)

1.3. felieton satyryczny Pawła Hertza i Jana Rojewskiego na łamach „Rzeczpospolitej” (1945, nr 84 [224], s. 4), zatytułowany Dobra posada. 


\section{przed 30 marca 1945}

1. Początek prac łódzkiego Wydziału Kultury i Sztuki.

Został powołany do życia przez Zarząd Miejski w Łodzi Wydział Kultury i Sztuki, którego zadaniem będzie współpraca z przedstawicielami wszystkich dziedzin kultury i sztuki, jak: teatru, plastyki, literatury i muzyki.

Siedziba Wydziału mieści się przy ul. Piotrkowskiej 104. (Wydziat kultury i sztuki, GL 1945, nr 79 [119], s. 4)

2. Do Łodzi przenosi się Centralna Żydowska Komisja Historyczna. Zajmuje lokal przy ul. Narutowicza 25.

Komisja powstała w początkach grudnia ub. r. w Lublinie, obecnie przeniosła się do Łodzi, gdzie pracuje jako placówka Ministerstwa Informacji i Propagandy.

Tematem prac komisji jest wyłącznie okres okupacji niemieckiej, okres prześladowań i krwawego terroru, który dał się we znaki szczególnie na odcinku żydowskim, na którym hitlerowcy czuli się najmniej skrępowani opinią publiczną.

Komisja gromadzi archiwum składające się z aktów SS, gestapo i Rad Żydowskich, których Niemcy nie zdążyli usunąć, z fotografii (m.in. pochodzących z gestapo), z czasopism, ulotek, wydawnictw prasy podziemnej, pamiętników - wreszcie zeznań naocznych świadków.

W zamierzeniach komisji leży m.in. wydanie drukiem dokumentów, fotografii, monografii poszczególnych miast oraz opracowanie poszczególnych odcinków historii, np. o udziale Żyda w polskim ruchu partyzanckim.

Komisja współpracuje $\mathrm{z}$ istniejącymi instytucjami historycznymi, z dyrekcją muzeum na Majdanku i Instytutem Socjologicznym. ([P], Żydowska komisja historyczna zbiera materiaty dotyczace okresu okupacji w Polsce, GL 1945, nr 79 [119], s. 4)

\section{1 marca 1945, Wielka Sobota}

1. Ukazują się świąteczne numery gazet.

1.1. W „Rzeczpospolitej” (1945, nr 86 [226]):

1.1.1. wstępny artykuł okolicznościowy pt. Alleluja

My, cośmy odrodzili się z klęski, potargali okowy i powstajemy do nowego życia - my, którzy walczymy ze złem u naszych granic i wewnątrz nich

- odczuwamy zawartą w nim [?] radość życia, młodej wiosny, tworzenia i postępu. (s. 1)

1.1.2. wiersz Jana Huszczy Legenda o dzwonie wielkanocnym z roku 1944 (s. 1) 


\subsection{3. programowy artykuł Jerzego Borejszy Przedwiośnie}

Po pięciu wiosnach niewoli - jesteśmy u progu pierwszej wiosny wolności. Od Bugu aż do Odry, od Bałtyku aż do Tatr powstają zręby nowego niepodległego życia państwowego, politycznego, gospodarczego i kulturalnego. Ta trzecia niepodległość Polski, ta trzecia wolność kraju i narodu jest jednak zupełnie inna, odmienna od tych wolności, jakie dotychczas znaliśmy. [...]

Trzecią wolność odzyskujemy dzięki walce czerwonoarmisty i żołnierza polskiego, uzbrojonego przez ZSRR. (s. 3)

1.1.4. felieton Jerzego Wyszomirskiego Chów na linie poświęcony zagadnieniom ortografii, zakończony następującym akapitem o wymowie politycznej:

Zakwalifikujmy obecną pisownię jako smutny spadek, pozostawiony nam przez tzw. sanację. Tępimy jej ducha we wszystkich dziedzinach życia. Reformujemy je na innych zasadach. Zreformujmy i pisownię, której doniosłości w dziedzinie kultury narodowej nikt nie zaprzeczy. Zreformujmy - to znaczy przywróćmy po prostu dawną - jasną, łatwą i logiczną. (s. 4)

\subsection{5. ideologicznie motywowany tekst Kazimierza Czachowskiego} o zadaniach literatury w epoce powojennej

W naszym życiu literackim, w naszych poglądach literackich tkwi jakaś bliżej nieuzasadniona obawa przed wprowadzeniem do twórczości literackiej zdecydowanej ideologii społecznej czy politycznej. I owszem, toleruje się, a nawet pochwala jakieś niedookreślone raczej nastroje niż przekonania, przeważnie bardzo górnolotne i mocno abstrakcyjne, do pomyślenia w każdej możliwej oczywistości społecznej, tylko właśnie nie w tej, z którą korzeniami jesteśmy zrośnięci. Kiedy jednak pisarz podejmuje istotnie aktualne zagadnienie społeczne, kiedy swój autorytet artystyczny rzuca na szalę walki politycznej, wtedy wytacza się wielkie działo szkodliwej sztuce tendencji i inne $\mathrm{w}$ tym rodzaju straszaki $\mathrm{z}$ dziecinnego pokoju. (K. Czachowski, Nie lękajmy się programu, s. 4)

1.1.6. zaproszenie pisarzy-amatorów do współpracy, sformułowane przez Adolfa Rudnickiego w imieniu łódzkiego oddziału ZZLP

Zarząd łódzkiego oddziału Zw. Zaw. Literatów Polskich upoważnił mnie do złożenia publicznego oświadczenia, że szukamy nowych, bezimiennych dotąd pisarzy. Chcemy widzieć wśród nas nowych ludzi. Przynieście nam wasze prace. Wszystko, co mamy najlepszego w dziedzinie oceny, zajmie się nimi. Szukamy was, jak zapewne wy nas szukacie. I tych, którzy na to zasługują, przygarniemy do nas - na dobre i na złe. (A. Rudnicki, Szukamy was, s. 5) 
1.1.7. satyryczna proza narracyjna Jana Huszczy pt. Ucieczka, wymierzona w praktyki szabrownicze - zapewne z odniesieniem do realiów łódzkich (s. 5)

1.2. w „Polsce Zbrojnej” (1945, nr 56):

1.2.1. artykuł wstępny Stanisława Ryszarda Dobrowolskiego

Jeszcze wczoraj spoczywał w lochu śmierci - rzucony tam przez posiepaków i przywalony kamieniem niewoli. Oprawcy - żołnierze nowoczesnego cezara, zbiry w stalowych hełmach obłąkańca, Kaliguli naszych czasów, zbrojni po zęby trzymali straże u grobowca [...].

Aż o którejś godzinie "grom przyszedł uderzyć" i złotym ciosem poraził posiepaków cezara. A w ślad za gromem nadbiegli skrzydlaci synowie wolności, stalowymi ostrzami podważyli płytę kamienną i odwalili ją. I wstał z martwych i dźwignął się w całym swoim majestacie i potędze - On, umęczony, zelżony Naród Polski i poraził ich ostatecznie, samym widokiem, że wstał. (S. R. D., [artykuł wstępny], s. 1)

\subsection{2. wiersz Dzwony Lucyny Krzemienieckiej (s. 1)}

1.2.3. orędzie wielkanocne p.o. dziekana polowego WP ks. ppłk. Stanisława Warchałowskiego

Alleluja! Radujmy się Polacy - że Ojczyzna nasza, choć leżała 5 lat zgnębiona, a już w 1939 roku przez Hitlera na zawsze pochowana i pogrzebana, przez Gestapo w tych latach cierniem ukoronowana, jednak po tylu mękach my dziś znów u siebie w domu gospodarzami. Opieka Boża nad naszym Narodem to sprawiła, że dała nam moc i bicz na prusaków w potędze Armii Czerwonej i genialnych Jej Wodzów - wodzów broniących się i zwyciężających - Słowiańszczyzny. (S. Warchałowski, Wesoły nam dziś dzień nastat, s. 3)

1.2.4. artykuł o „demokratyzacji” Polski, zawierający zwięzły program zmian w obszarze kultury

Oświata i kultura, przebudowywane na nowych zasadach, dążą do objęcia jak najszerszych rzesz narodu. Wiedza dla ludu, sztuka dla mas - oto hasło przyświecające pracownikom kultury. Uczony, pisarz, artysta, nauczyciel zyskują w Polsce nowe i rozległe możliwości działania i, zgodnie z tem, nowe prawa. (S.B., Święto Wolnej Polski, s. 3)

1.2.5. tekst Zofii Nałkowskiej Spalone miasto poświęcony zburzonej Warszawie (s. 4)

1.2.6. proza Stanisława Piętaka List do żotnierza (s. 4)

1.2.7. artykuł S. R. Dobrowolskiego o organizujących się placówkach przedszkolnych (Młodości, wszystkiego dziedzicu!..., s. 4)

1.2.8. wspomnienia świąt wielkanocnych obchodzonych podczas wojny - Mieczysława Moczara (Święto "chłopców z lasu”, s. 5), poety Andrzeja Nowickiego (Wielkanoc w Oflagu, s. 5) i Tadeusza Oleńskiego (Święcone w 1-szej Armii, s. 5) 
1.2.9. Rum na święta (epizod frontowy) - relacja Tadeusza Jacka Rolickiego (s. 7)

1.3. W „Głosie Ludu” (1945, nr 80 [120]):

1.3.1. niepodpisany artykuł wstępny Wiosna Narodu Polskiego (zapewne autorstwa Romana Werfla), o jednoznacznej wymowie ideologiczno-politycznej)

Szaleńcza, antysowiecka polityka reakcyjnej kliki emigrantów londyńskich, którzy prawem kaduka uzurpowali sobie miano „rządu”, doprowadziła do całkowitego odosobnienia Polski na arenie międzynarodowej.

Groziło to całkowitym impasem sprawie silnej Polski. I wtedy jedynie Polska Partia Robotnicza śmiało wysunęła myśl o sojuszu Polski ze Związkiem Radzieckim jako głównej podstawowej wytycznej polskiej polityki zagranicznej. (s. 1)

\subsection{2 wiersz Marii Castellatti Próg ojczyzny (s. 2)}

1.3.3. nota Znany malarz Picasso - komunista (s. 2)

1.3.4. artykuł Jana Kotta o „Trzeciej Niepodległości”

Kraków i Łódź, dwa najważniejsze dziś skupienia polskiej inteligencji, dwa najważniejsze środowiska literackie i artystyczne, gotowe są zapomnieć, że wojna trwa nadal. [...]

Fundament trzeciej Niepodległości założony został w latach okupacji przez Polską Partię Robotniczą.

Reakcja polska usiłowała za wszelką cenę zdobyć dla siebie pisarzy. Miała do dyspozycji pieniądze, propagandę, prasę i jako ostatni argument rewolwery płatnych zbirów. Pisarze w olbrzymiej większości pozostali wierni ideałom demokracji. Ale niewielu tylko w mrokach konspiracyjnej pracy potrafiło dostrzec główny nurt walki o niepodległość, dostrzec korzenie, zanim wzrosły pędy.

Inaczej jest dzisiaj. Historia stała się niejako publiczna. Historia dzieje się na oczach nas wszystkich! Hierarchia zdarzeń stała się jasna! Wielkie sprawy Trzeciej Niepodległości znaleźć muszą swój wyraz w literaturze. Z Łodzi i Krakowa musimy dostrzec i ukazać czytelnikowi walkę, jaka toczy się na wsi, na frontach, w Warszawie. Musimy uchwycić główny nurt. Uchwycimy! (Główny nurt, s. 3)

1.3.5. wspomnieniowy artykuł Stefana Lichańskiego, byłego więźnia KL Auschwitz, zbudowany z szeregu patetycznych apostrof do zmarłych, łączący symbolikę pasyjno-rezurekcyjną z zagadnieniami historyczno-politycznymi (między innymi z elementami kłamstwa katyńskiego)

Umarli, dzisiaj jest święto Zmartwychwstania.

Ale ku tamtemu wraca uparcie myśli, ku wielkopiątkowemu zmierzchowi, ku waszej Golgocie. 11 listopada 1941 r. rozstrzelano pięćdziesięciu kilku więźniów: oficerów służby czynnej i rezerwy, powstańców wielkopolskich i górnośląskich. Zimą 1941/42 wymordowano pewnej nocy gazem trującym 700 chorych. W sąsiadującym z naszym obozem - obozie jeńców sowieckich wymordowano w przeciągu trzech miesięcy przeszło 
30.000 ludzi. Niektóre transporty więźniów sowieckich szły do komór gazowych prosto z pociągów, którymi je przywieziono, innych mordowano znaną katyńską metodą: strzał w tył czaszki, innym zastrzykiwano dożylnie fenol - podobnie jak naszym gruźlikom. [...]

Cóż z tego, że mijają dni, tygodnie, miesiące i lata? Tamto trwa. Ulicą jedzie wielki samochód ciężarowy. Ładunek szczelnie okryty brezentem. Boże, to ten sam! Wiezie trupy sowieckich żołnierzy z miejsca stracenia. Człowieku, opamiętaj się! Przecież to było więcej niż trzy lata temu! Przecież to Łódź, nie Oświęcim! A tak, prawda... Przecież to Łódź... Przecież to Łódź... Boże, zlituj się! Boże, daj zapomnieć! (O Zmartwychwstaniu, s. 3)

1.3.6. teksty wymierzone w Armię Krajową, skrajnie negatywnie przedstawiające powstanie warszawskie: Rekolekcje narodowe S. R. Dobrowolskiego (s. 5); relacja wspomnieniowa $W$ sztabie AK podczas powstania warszawskiego, sygnowana podpisem „łączniczka” (s. 4-5)

1.3.7. wiersz Jana Kotta Do historii (s. 5)

1.3.8. wspomnieniowy tekst Krystyny Żywulskiej (właśc. Sonii Landau) Wielkanoc w Oświęcimiu (s. 6)

1.3.9. wiersz Do Grecji Mieczysława Jastruna, napisany w roku 1942 (s. 6)

1.3.10. felieton krytycznoliteracki Spory rodzinne Artura Sandauera, traktujący o poezji zrozumiałej i niezrozumiałej (s. 5)

1.3.11. Wiosenny wiersz Seweryna Pollaka, napisany w roku 1941 (s. 8)

1.3.12. informacja o pracach nad pierwszymi spektaklami Teatru Miejskiego

Dyrekcja Teatru Miejskiego w Łodzi przygotowuje na inaugurację Beaumarchais'go Cyrulik Sewilski i Wesele Figara w jednym rzucie widowiskowym pt. Sto szaleństw. Widowisko inscenizuje dyr. H. Szletyński przy udziale T. Sygietyńskiego (muzyka) i Wł. Daszewskiego (dekoracja). (Teatr Miejski, s. 8)

\section{marzec}

1. Z Lublina do Łodzi zostaje przeniesiona Centralna Szkoła Partyjna PPR.

Centralna Szkoła Partyjna PPR, która od marca 1945 r. funkcjonowała przy ul. Wólczańskiej [...], miała kształcić kadry dla aparatu partyjnego. Ale od pierwszej chwili stała się czymś znacznie większym - rozwijającym się i promieniującym środowiskiem ideologicznym. Łódź była wówczas drugą stolicą, w życiu intelektualnym zaś niewątpliwie pierwszą. Tu koncentrowało się to co nowe i prężne w literaturze, publicystyce, nauce, sztuce. Tu gromadziły się i kształtowały kadry naszego życia intelektualnego. Ludzie ci wiedzieli, że mają budować socjalizm, ale co to oznacza w sferze ich specyficznej działalności, najczęściej nie wiedzieli wcale. (Adam Schaff, Łódzkie wspomnienia, [w:] tenże, Tranzytem przez Łódź, Łódź 1964, s. 36) 


\section{marzec lub kwiecień 1945}

1. Z Krakowa przylatuje do Łodzi Eryk Lipiński. Pierwszą noc spędza w mieszkaniu Larysy i Zbigniewa Mitznerów.

Funkcję kierownika [Wojewódzkiego Urzędu Propagandy w Krakowie] pełniłem tylko kilka dni. Do Krakowa przyjechał Jerzy Borejsza, dał mi dwa tysiące złotych (do dziś nie wiem za co) i zorganizował mi podróż kukuruźnikiem do Łodzi, która w tamtych czasach stawała się kulturalną stolicą Polski. Z tą podróżą związane były pewne emocje. Już na lotnisku zobaczyłem, że pilot stoi obok samolociku, bezradnie drapiąc się w głowę i przyglądając się rozmaitym śrubkom, kółkom i sprężynkom. Poinformował mnie, że coś się popsuło, ale nie wie gdzie i co. Z dużym niepokojem obserwowałem więc jego wysiłki, ale kiedy skończył i zapytał mnie, czy nie boję się lecieć, odpowiedziałem zgodnie z prawdą, że po pięciu latach okupacji niczego już się nie boję. Dolecieliśmy do Łodzi, chociaż kiedy kukuruźnik opuścił się nagle kilkadziesiąt metrów w dół (trafił na „dziurę" powietrzną), omal z niego nie wypadłem.

W Łodzi pierwszą noc spędziłem u Mitznerów, śpiąc na waleta z Adamem Mauersbergerem, ale następnego dnia już miałem pokój w Grand Hotelu i dałem znać żonie, że może przyjechać. Pokój ten dotychczas zajmował Marian Eile, ale akurat wyjeżdżał do Krakowa, żeby zorganizować wydawanie nowego tygodnika ilustrowanego, który miał się nazywać „Przekrój”. Nie poinformowaliśmy recepcji hotelu o dokonanej zmianie i przez kilka miesięcy zwracano się tam do mnie per „panie Eile”.

Przed wyjazdem Eile przekazał mi dokończenie dekoracji sali projekcyjnej przy ulicy Narutowicza. Był to mój pierwszy zarobek w Łodzi. Już od paru tygodni wychodziły w Łodzi wznowione „Szpilki”, ale redagujący je wówczas Lec i Pasternak nie kwapili się z propozycją współpracy ani dla Mitznera, ani dla mnie, którzyśmy to pismo przed wojną założyli i redagowali. (E. Lipiński, Pamiętniki, Warszawa 1990, s. 143-144)

\section{B I B L I O GRA A I A}

\section{OPRACOWANIA}

Fik M., Kultura polska po Jatcie. Kronika lat 1944-1981, t. I, Warszawa 1991. J.R., Dotychczasowy dorobek „Czytelnika”, "Książka i Kultura” 1945, nr 1, s. 8.

\section{KORESPONDENCJA, WSPOMNIENIA}

Dąbrowska M., Dzienniki 1914-1965, pierwsze pełne wydanie w 13 tomach [bez opracowania edytorskiego] pod kierunkiem prof. dr. hab. T. Drewnowskiego, t. 5, Warszawa 2009.

Drewnowski T., Tyle hałasu - o nic? Wspomnienia, Warszawa 1982.

Hertz P., Iwaszkiewiczowie A. i J., Korespondencja, t. 1, Warszawa 2015.

Kott J., Przyczynek do biografii. Zawat serca, Kraków 1994. 
Lipiński E., Pamiętniki, Warszawa 1990.

Nałkowska Z., Dzienniki, t. 6: 1945-1954. Część 1 [1945-1948], opracowanie, wstęp i komentarz H. Kirchner, Warszawa 2000.

Rostworowski T. TJ, Szerzyć Królestwo. Wspomnienia i dzienniki 1939-1972, wybór i oprac. T. Pronobis TJ i S. J. Rostworowski, Warszawa 2004.

Schaff A., Łódzkie wspomnienia, [w:] Tranzytem przez Łódź, Łódź 1964.

Wende J.K., Ta ziemia od innych droższa..., Warszawa 1981.

Zaremba J., Było i tak. Wspomnienia, Wrocław 1976.

TEKSTY Z PRASY ŁÓDZKIEJ (1945)

\section{Artykuły propagandowo-ideologiczne}

S. B., Święto Wolnej Polski, PZ 1945, nr 56, s. 3.

Dobrowolski S. R., Powracajacy cudem, PZ 1945, nr 37, s. 3.

Dobrowolski S. R., Rekolekcje narodowe, GL 1945, nr 80 (120), s. 5.

Z. K., Pan „prezydent”, DŁ 1945, nr 7, s. 2.

łączniczka, W sztabie AK podczas powstania warszawskiego, GL 1945, nr 80 (120), s. $4-5$.

Łódź robotnicza o Konferencji Krymskiej, GL 1945, nr 41 (80), s. 4.

Nowak T. S., Pomnik Kościuszki na Placu Wolności, GL 1945, nr 41 (80), s. 3.

Polscy pupile Goebbelsa, GL 1945, nr 33 (72), s. 3.

Werfel R., Rocznica Komuny Paryskiej, GL 1945, nr 67 (107), s. 3.

Wiosna Narodu Polskiego, GL 1945, nr 80 (120), s. 1.

Włodarkiewicz F., Drogi i bezdroża polskiej reakcji, (DŁ 1945, nr 7, s. 3).

\section{Felietony}

Dobrowolski S. R., Powitanie Łodzi, GL 1945, nr 59 (98), s. 4.

Hertz P., Rojewski J., Dobra posada, RZ 1945, nr 84 (224), s. 4.

Sandauer A., Spory rodzinne, GL 1945, nr 80 (120), s. 5.

Wyszomirski J., Przebierańcy, RZ 1945, nr 80 (220), s. 2-3.

Informacje i relacje prasowe

2 księgarnie Spótdzielni Wyd. „Ksiażka”, GL 64 [104], s. 4.

Aleksander Zelwerowicz w Łodzi, RZ 1945, nr 75 (215), s. 4.

Babisiak S., Defilada Wojska Polskiego, RZ 1945, nr 42 (186), s. 3.

baj., Zespót pieśni i tańca I-go Frontu Białoruskiego, GL 1945, nr 54 (93), s. 4.

Dziennikarze zagraniczni zwiedzili Łódź, GL 1945, nr 30 (69), s. 4.

Dzień szkoty polskiej będzie obchodzony w Łodzi dnia 4 marca, GL 1945, nr 53 (92), s. 4.

D. E., Pierwszy poranek literacki w Łodzi, R 1945, nr 59 (89), s. 3.

Egzaminy w Studio Dramatycznym, RZ 1945, nr 76 (216), s. 4.

J. F., Uroczyste otwarcie Głównej Księgarni Wojskowej, PZ 1945, nr 29, s. 1.

Film będzie odzwierciedlat dzieje narodu. Zdjęcia z powstania warszawskiego. Operator filmowy na polu walki. Zamierzenia na przyszłość. Rozmowa z mjr. Aleksandrem Fordem, GL 1945, nr 30 (69), s. 4.

H., "Złaczmy się w wysitku z nasza ukochana Armia!". Akademia ku czci Wojska Polskiego, PZ 1945, nr 34, s. 4. 
A.J., Łódzki Dom Żotnierza, PZ 1945, nr 38, s. 4.

Jan Kiepura o pomocy dla Polski, GL 1945, nr 31 (70), s. 3.

Kina łódzkie, DŁ 1945, nr 6, s. 3.

Kolejarze Łodzi witają Rzad Tymczasowy Polski i Marszałka Stalina, DŁ 1945, nr 3, s. 2.

Komitet odbudowy Warszawy zorganizowany, GL 1945, nr 66 [106], s. 4.

Koncert orkiestry symfonicznej, DŁ 1945, nr 7, s. 4.

Konferencja wojewódzka PPR rozpoczęła się wczoraj w Łodzi przy udziale 550 delegatów, GL 1945, nr 41 (80), s. 3.

Literatura i sztuka, GL 1945, nr 58 (97), s. 3.

Międzynarodowy Dzień Kobiet, PZ 1945, nr 36, s. 4.

Mikułko A., Poranek Literacki w Łodzi, RZ 1945, nr 67 (207), s. 3.

Min. Rzymowski w Łodzi, GL 1945, nr 63 [102], s. 4.

Minister Matuszewski w Łodzi, DŁ 1945, nr 9, s. 3.

Naczelny Dowódca W.P. w redakcji „Polski Zbrojnej”, PZ 1945, nr 30, s. 1.

Nowy Zarząd Zw. Literatów, GL 1945, nr 68 (108), s. 4.

Obrady stronnictw politycznych w Łodzi. Wojewódzka Konferencja PPS, GL 1945, nr 55 (94), s. 4.

Odradza się zycie kulturalne Łodzi, GL 1945, nr 31 (70), s. 4.

Organizacja Uniwersytetu w Łodzi, DŁ 1945, nr 10, s. 4.

Oświata w Łodzi, DŁ 1945, nr 7, s. 4.

Otwarcie Robotniczego Domu Kultury, RZ 1945, nr 75 (215), s. 4.

Otwarcie świetlicy PPR Dzielnica Górna Prawa, GL 1945, nr 76 (116), s. 4.

Otwarcie świetlicy w b. zakładach Poznańskiego, GL 1945, nr 63 (102), s. 4.

Otwarcie uniwersytetu w Łodzi nastapi już w marcu. Uniwersytet tódzki będzie miat

16 wydziałów. Prace organizacyjne są w petnym toku, GL 1945, nr 32 (71), s. 4.

(P), Żydowska komisja historyczna zbiera materiaty dotyczace okresu okupacji $w$ Polsce, GL 1945, nr 79 (119), s. 4.

W. P., Radiofonizacja Polski. (Na podstawie wywiadu z dyrektorem Polskiego Radia, ob. Billigiem), PZ 1945, nr 37, s. 4.

Państwowe Konserwatorium powstaje w Łodzi, GL 1945, nr 52 (91), s. 4.

Polskie Radio w Łodzi, DŁ 1945, nr 6, s. 4.

Prace w zakresie szkolnictwa postępuja, DŁ 1945, nr 10, s. 3.

Prasa na wyzwolonych terenach, DŁ 1945, nr 6, s. 2.

Prezydent Bierut jest głęboko wzruszony powitaniem, jakie mu zgotowała Łódź i Kutno, PZ 1945, nr 30, s. 1.

Prezydent K.R.N. i Naczelny Dowódca W.P. wśród robotników łódzkich, PZ 1945, nr 29, s. 1.

Prezydentem m. Łodzi zostat ob. Mijal, GL 1945, nr 57 (96), s. 4.

Przeniesienie siedziby Rzadu Tymczasowego do Warszawy, DŁ 1945, nr 4, s. 1.

Ratujmy ksiażkę polska, DŁ1945, nr 9, s. 4.

Radiostacja tódzka będzie odbudowana. Megafony będa rozmieszczone na wszystkich ulicach, GL 1945, nr 31 (70), s. 4.

Robotnicze Domy Kultury w Polsce, GL 1945, nr 59 (98), s. 3.

Stefańczyk M., Powstaja 2 teatry w Łodzi, GL 1945, nr 32 (71), s. 4.

Szletyński dyrektorem Teatru Miejskiego, DŁ 1945, nr 9, s. 3.

Święto młodzieży szkolnej, GL 1945, nr 55 (94), s. 4.

Teatr miejski, GL 1945, nr 80 (120), s. 8. 
Uchwaty R.N. Stronnictwa Ludowego, GL 1945, nr 79 (119), s. 3.

W Łodzi powstaje Filharmionia. (Wywiad ze Zdzisławem Górzyńskim), GL 1945, nr 40 , s. 4.

Wardasówna M., Rozwój polskiej komunikacji lotniczej, RZ 1945, nr 78 (218), s. 3.

Wojew. zjazd kierowników Informacji i Propagandy, GL 1945, nr 63 (102), s. 4.

Wydziat kultury i sztuki, GL 1945, nr 79 (119), s. 4.

Występy artystów radzieckich wywołały szczery zachwyt wśród mieszkańców robotniczej Łodzi, GL 1945, nr 54 (93), s. 4.

Z kroniki kulturalno-literackiej, RZ 1945, nr 82 (222), s. 4.

Z sekretariatu Państwowego Uniwersytetu w Łodzi, GL 1945, nr 64 (104), s. 4.

Z życia kulturalnego Łodzi, DŁ 1945, nr 8, s. 4.

Z życia Partii, GL 1945, nr 57 (96), s. 4.

Zagościński J., Uniwersytet w Łodzi, RZ 1945, nr 63 (203), s. 3.

Zagraniczni dziennikarze w Łodzi, DŁ 1945, nr 5.

Zamierzenia Ministerstwa Oświaty, GL 1945, nr 63 (102), s. 4.

Zarząd Gtówny „Wici” przenióst się do Łodzi, GL 1945, nr 69 (109), s. 4.

Zebranie literatów w Łodzi, RZ 1945, nr 42, s. 4.

Ziemak S., Dzień słońca i wzruszenia, RZ 1945, nr 42 (186), s. 3.

Zjazd Stronnictwa Ludowego, GL 1945, nr 75 (115), s. 4.

Znany malarz Picasso - komunista, GL 1945, nr 80 (120), s. 2.

m.h.ż., Poczta łódzka pracuje, RZ 1945, nr 78 (218), s. 4.

Życie kulturalne, PZ 1945, nr 36, s. 4.

\section{Korespondencje $\mathbf{z}$ frontu}

Broniewska J., Niemiecka „przeprowadzka”, PZ 1945, nr 37, s. 3.

Broniewska J., Jeńcy, PZ 1945, nr 35, s. 3.

Broniewska J., Żotnierz idzie jak huragan... Rozmowa z Dowództwem 1 Armii Polskiej - gen. Popławskim i gen. Strażewskim, PZ 1945, nr 34, s. 2.

Holland H., W kierunku morza. Oddziały polskie zajęty miasto Tempelburg, PZ 1945, nr 37, s. 2.

Rolicki T. J., Idziemy naprzód na S., PZ 1945, nr 34, s. 2.

Rolicki T. J., Rum na święta (epizod frontowy), PZ 1945, nr 56, s. 7.

Rolicki T. J., Zadzierżystość, PZ 1945, nr 35, s. 2.

\section{Listy do redakcji gazet}

Depesza Juliana Tuwima do mieszkańców Łodzi, DŁ 1945, nr 4, s. 1.

Minkiewicz J., List do Redakcji, RZ 1945, nr 80 [220], s. 4 [ws. udziału J. Minkiewicza w poranku literackim 25 marca 1945].

\section{Ogłoszenia, wezwania, zachęty}

I Zebranie Miejskiej Rady Narodowej m Łodzi, GL 1945, nr 54 (93), s. 4.

Biblioteka Wojewódzkiego Urzędu Informacji i Propagandy, DŁ 1945, nr 6, s. 4.

Czytelnia, GL 1945, nr 61 (100), s. 4.

Komunikaty, DE 1945, nr 2, s. 4.

Koncert zespołu Armii Czerwonej w Łodzi, GL 1945, nr 51 (90), s. 4.

Książi dla rannych żotnierzy rosyjskich, RZ 1945, nr 76 (216), s. 4.

"Kwadrans Literacki", RZ 1945, nr 43 (187), s. 4. 
O nowy Uniwersytet Łódzki, DŁ1945, nr 9, s. 4.

Otwarcie Uniwersytetu w Łodzi, GL 1945, nr 70 (110), s. 4.

Państwowy Instytut Sztuki Teatralnej, GL 1945, nr 76 (116), s. 4.

Ratujmy polska książke wojskowa, PZ 1945, nr 38, s. 4.

Rudnicki A., Szukamy was, RZ 1945, nr 86 (226), s. 5.

Zapisy do szkót średnich, GL 1945, nr 30 (69), s. 3.

Zebranie członków b. Zaiksu, GL 1945, nr 67 (107), s. 4.

Zebranie dyrektorów szkót, DŁ 1945, nr 3, s. 4.

Zebranie Str. Demokratycznego, GL 1945, nr 65 (105), s. 4.

\section{Program „nowej kultury”}

Czachowski K., Nie lękajmy się programu, RZ 1945, nr 86 (226), s. 4.

Kott J., Główny nurt, GL 1945, nr 80 (120), s. 3.

Lec S. J., [artykuł wstępny], Szpilki" 1945, nr 1, s. 2.

Odrodzenie kultury polskiej, GL 1945, nr 73 (113), s. 1.

\section{Recenzje}

baj., "Wista do Gdańska” w Domu Żotnierza, GL 1945, nr 65 [105], s. 4.

"Tęcza" (recenzja z filmu), DŁ 1945, nr 2, s. 4.

jw. [Jerzy Wyszomirski], „,Wesele” w Teatrze Wojska Polskiego, RZ 1945, nr 79 (219), s. 3.

Zar. I., Teatr zrodzony z tęsknoty, RZ 1945, nr 83 (223), s. 4 [dot. programu Od

Oki do Wisty, pokazanego w Teatrze Wojska Polskiego 25 marca 1945].

\section{Reportaże}

Dobrowolski S. R., Listy z Oświęcimia, GL 1945, nr 72 [112], s. 3.

\section{„Sprawa chłopska" na łamach prasy}

Bułharowska H., Ten, co na wozie wjechat do historii, RZ 1945, nr 79 (219), s. 3.

Drewnowski J., Kamieńczyk, PZ 1945, nr 37, s. 4.

Drewnowski J., Samopomoc. Kartki z dziennika podróży, W 1945, nr 2 (9), s. 2.

Król J. A., Obszarnik bez ziemi, W 1945, nr 2 (9), s. 1.

\section{Utwory literackie na łamach prasy}

Castellatti M., Próg ojczyzny, GL 1945, nr 80 (120), s. 2.

Huszcza J., Legenda o dzwonie wielkanocnym, RZ 1945, nr 86 (226), s. 1.

Huszcza J., Ucieczka [satyryczna proza narracyjna], RZ 1945, nr 86 (226), s. 5.

Hertz P., *** [Jaka ty będziesz? Czy dwukolorowa...] [wiersz], RZ 1945, nr 80 (220), s. 3.

Jastrun M., Do Grecji [wiersz], GL 1945, nr 80 (120), s. 6.

Kott J., Do historii [wiersz], GL 1945, nr 80 (120), s. 5.

Krzemieniecka L., Dzwony [wiersz], PZ 1945, nr 56, s. 1.

Lewin L., Apel [wiersz], PZ 1945, nr 37, s. 3.

Nałkowska Z., Spalone miasto [obrazek-reportaż], PZ 1945, nr 56, s. 4.

Pasternak L., Bruk emigracji [wiersz], "Szpilki” 1945, nr 1, s. 2.

Piętak S., List do żotnierza [opowiadanie], PZ 1945, nr 56, s. 4.

Piętak S., Więzień [opowiadanie], PZ 1945, nr 33, s. 2-3.

Poldino, Na ostatnia mowę Hitlera [fraszka], GL 1945, nr 30 (69), s. 3.

Pollak S., Pottier [wiersz], GL 1945, nr 67 (107), s. 3. 
Pollak S., Wiosenny wiersz, GL 1945, nr 80 (120), s. 8.

\section{Wspomnienia publikowane na łamach prasy}

Kruczkowski L., Nazajutrz po powrocie, GL 1945, nr 72 (112), s. 3.

Lichański S., O Zmartwychwstaniu, s. 3, GL 1945, nr 80 (120), s. 3.

Lichański S., Oświęcim. Ze wspomnień więźnia, W 1945, nr 2 (9), s. 6.

Moczar M., Święto „chłopców z lasu”, PZ 1945, nr 56, s. 5.

Nowicki A., Wielkanoc w Oflagu, PZ 1945, nr 56, s. 5.

Oleński T., Święcone w 1-szej Armii, PZ 1945, nr 56, s. 5.

Żywulska K. (właśc. Sonia Landau), Wielkanoc w Oświęcimiu, GL 1945, nr 80 (120), s. 6.

\section{Zapowiedzi imprez kulturalnych}

„Dziś gramy dla cywilów", PZ 1945, nr 31, s. 4 [dot. widowiska Dziś gramy dla cywilów wystawianego w sali Teatru Miejskiego przez "Zespół Artystyczny Armii Polskiej" 3, 4, 5 i 6 marca 1945].

„Nasza jest Łódź", RZ 1945, nr 79 [219], s. 4 [dot. programu artystycznego Nasza jest Łódź prezentowanego w Sali Śpiewaków 24 i 25 marca 1945].

Od Oki do Wisty, RZ 1945, nr 78 [218], s. 4 [dot. „wielkiego poranka literackiego” Od Oki do Wisty, prezentowanego w Teatrze Wojska Polskiego 25 marca 1945].

„Od Oki do Wisty", GL 1945, nr 74 [114], s. 4 [jw.].

Otwarcie Robotniczych Domów Kultury, GL 1945, nr 67 (107), s. 4 [dot. uroczystego otwarcia Robotniczego Domu Kultury przy ul. Piotrkowskiej 243; 18 marca 1945].

Poranek literacki, GL 1945, nr 71 [111], s. 4 [dot. poranka literackiego w sali przy ul. 11 Listopada 21; 25 marca 1945].

Teatr Dramatyczny Armii, DŁ 1945, nr 8, s. 4 [dot. spektaklu Radcy pana Radcy, granego 11 lutego 1945].

Teatr Wojska Polskiego, RZ 1945, nr 89 [229], s. 4 [dot. inscenizacji Wesela $i$ programu Od Oki do Wisty w Teatrze Wojska Polskiego, granych na przełomie marca i kwietnia 1945, oraz przedstawień planowanych - Dożywocia i Fantazego].

Zgromadzenie publiczne, GL 1945, nr 73 [113], s. 4 [dot. „zgromadzenia publicznego" w hali sportowej na terenie Parku Poniatowskiego; 24 marca 1945].

\section{Inne teksty prasowe}

S.R.D., [artykuł wstępny], PZ 1945, nr 56, s. 1.

Dobrowolski S. R., Młodości, wszystkiego dziedzicu!..., PZ 1945, nr 56, s. 4.

„Głos Ludu” w Łodzi, GL 1945, nr 29 [68], s. 1.

Karaczewski A., [nota o przenosinach redakcji „Robotnika” do Łodzi] R 1945, nr 33 [63], s. 1.

Łódź, DŁ 1945, nr 1, s. 1.

Łódź - miasto pracy i walki, GL 1945, nr 29 (68), s. 1.

Pollak S., Maksym Gorkij, GL 1945, nr 76, s. 3.

Przemówienie przez radio Ministra Informacji i Propagandy tow. St. Matuszewskiego, R 1945, nr 33 (63), s. 2.

Warchałowski S., Wesoły nam dziś dzień nastał, PZ 1945, nr 56, s. 3. 


\section{STRESZCZENIE}

Publikacja niniejsza, fragment Kalendarium łódzkiego życia kulturalnego w latach 1945-1946, obejmuje swoim zakresem luty i marzec roku 1945, miesiące organizowania się kultury po przeszło pięciu latach niemieckiego terroru okupacyjnego. $W$ dziejach miasta był to okres szczególny - wobec niemal całkowitego zburzenia Warszawy przez Niemców, na terenie Łodzi ulokowały się niektóre spośród komunistycznych urzędów, zaczęli tu także zjeżdżać ważni przedstawiciele życia umysłowego i kulturalnego. Oferowano im mieszkania, pracę $\mathrm{w}$ dynamicznie rozwijającej się, kontrolowanej przez władzę prasie oraz w tworzonych naprędce instytucjach kultury i uczelniach.

Autor tekstu próbuje - poprzez szczegółową denotację faktów z pogranicza historii, polityki, życia umysłowego i artystycznego - przedstawić mechanizmy i dynamikę najwcześniejszego etapu kulturowo-ideologicznej rewolucji przeprowadzonej w Polsce w latach 1945-1948.

\section{Słowa kluczowe}

Łódź w roku 1945, prasa komunistyczna, łódzkie instytucje kultury, powojenne losy pisarzy, kalendarium, łódzkie życie literackie, propaganda komunistyczna

\section{S U M M A RY}

\section{Calendar of cultural life in Lodz February-March 1945}

This publication - an extract from Calendar of Cultural Life in Lodz between 1945 and 1946 (Kalendarium tódzkiego życia kulturalnego w latach 1945-1946) - focuses on the period of February and March 1945, i.e. the months during which cultural life was reorganised after more than five years of German occupation and Nazi terror. In the history of Lodz, this was a peculiar period - in the face of the virtually complete annihilation of Warsaw, Lodz became the home for some of the Communist offices and was visited by prominent representatives of intellectual and cultural life. They were offered apartments and jobs in the state-controlled press and hastily established cultural institutions and universities.

Through a detailed denotation of facts related to history, politics, and intellectual and artistic life, the author of the text makes an attempt to present the mechanisms and the dynamics of the earliest stage of the cultural and ideological revolution implemented in Poland between 1945 and 1948.

\section{Keywords}

Lodz in 1945, Communist press, cultural institutions in Lodz, post-war fates of writers, calendar, literary life in Lodz, Communist propaganda 